\title{
Description of a hybrid ice sheet-shelf model, and application to Antarctica
}

\author{
D. Pollard ${ }^{1}$ and R. M. DeConto ${ }^{2}$ \\ ${ }^{1}$ Earth and Environmental Systems Institute, Pennsylvania State University, University Park, PA, USA \\ ${ }^{2}$ Department of Geosciences, University of Massachusetts, Amherst, MA, USA
}

Correspondence to: D. Pollard (pollard@essc.psu.edu)

Received: 2 April 2012 - Published in Geosci. Model Dev. Discuss.: 4 May 2012

Revised: 3 August 2012 - Accepted: 4 September 2012 - Published: 17 October 2012

\begin{abstract}
The formulation of a 3-D ice sheet-shelf model is described. The model is designed for long-term continentalscale applications, and has been used mostly in paleoclimatic studies. It uses a hybrid combination of the scaled shallow ice and shallow shelf approximations for ice flow. Floating ice shelves and grounding-line migration are included, with parameterized ice fluxes at grounding lines that allows relatively coarse resolutions to be used. All significant components and parameterizations of the model are described in some detail. Basic results for modern Antarctica are compared with observations, and simulations over the last 5 million years are compared with previously published results. The sensitivity of ice volumes during the last deglaciation to basal sliding coefficients is discussed.
\end{abstract}

\section{Introduction}

This paper describes the formulation of a combined ice sheetshelf model, some aspects of which have been included in earlier papers (Pollard and DeConto, 2007, 2009; henceforth PD07, PD09), but many have not. Here, a full model description is presented, including recently added features that are being used in current work (Pollard and DeConto, 2012; henceforth PD12).

Early numerical 3-D ice sheet models used the shallow ice approximation (SIA), i.e., scaled dynamical equations appropriate for large-scale grounded ice flow dominated by vertical shear (" $\partial \mathrm{u} / \partial \mathrm{z}$ ") and basal stress locally balancing the gravitational (surface-slope) driving stress (e.g., Andrews and Mahaffy, 1976; Budd and Smith, 1979). Later, the need to include floating ice shelves, fast flowing ice streams (with very low basal drag) and grounding-line migration emerged, for instance to model marine collapses of the West Antarctic Ice Sheet. For shelves and streams, flow is dominated by horizontal stretching (“ $\partial \mathrm{u} / \partial \mathrm{x}$ ”) and a different set of scaled equations is appropriate using the shallow shelf approximation (SSA, also called shelfy stream) (Morland, 1982; MacAyeal, 1989, 1996). This was first attempted in 3-D models in the late 1990's, by applying either the SIA or SSA equations in different specified regions with matching at the boundaries (Hulbe and MacAyeal, 1999; Huybrechts and de Wolde, 1999; Huybrechts, 2002; Ritz et al., 2001; cf. Budd et al., 1994).

However, ice-stream flow can consist of both vertical shear and horizontal stretching, and its boundaries are not always amenable to simple parameterization; also, more rigorous treatment of the grounding zone is needed for accurate simulations of grounding-line migration (Schoof, 2007). Models with more rigorous (i.e., less scaled) higher-order or fullStokes formulations of the dynamical equations are available (e.g., Pattyn, 2002; Seddik et al., 2012), which capture both modes of flow, but are computationally expensive and are not currently feasible for long-term continental-scale applications. The problem has been addressed by a number of hybrid models, which use heuristic superpositions of the depth-integrated SIA and SSA equations (Bueler and Brown, 2009; Winkelmann et al., 2011; Goldberg, 2011; formalism in Schoof and Hindmarsh, 2010; different approaches in Marshall and Clarke, 1997; Hubbard, 2006; early steps in Alley and Whillans, 1984; van der Veen, 1985). Although these models are not rigorous, their performance can be tested against higher-order/full-Stokes models in simple scenarios 
as noted below, and are feasible for long-term large-scale applications.

The model described here is a hybrid model, most similar to Winkelmann et al. (2011) and Goldberg (2011). Our dynamical equations fall into type L1L2 of Hindmarsh's (2004) categories. An additional measure is taken to improve simulation of grounding zones, where the Schoof (2007) parameterization is imposed as a condition on ice flux across the grounding line. This enables grounding-line migration to be simulated reasonably accurately without the need for much higher resolution (Schoof, 2007; Gladstone et al., 2010a, 2012a; Pattyn et al., 2012a).

The model also includes standard equations for the evolution of ice thickness, internal ice temperatures, and the bedrock response under the ice load. An optional coupling with a sediment model, with explicit quarrying/abrasion, transport and deposition of deformable sediment under the ice, is fully described in Pollard and DeConto (2003, 2007) and is not covered here. There is no explicit basal hydrologic component in the current model.

The model is designed to be feasible for long-term $O\left(10^{7} \mathrm{yr}\right)$ continental-scale applications. Early model versions without floating ice (SIA only) were applied to paleo Antarctica (DeConto and Pollard 2003a, b; Pollard and DeConto, 2003, 2005; Pollard et al., 2005; DeConto et al., 2007) and to other ice sheets and times (Herrmann et al., 2003, 2004; Pollard and Kasting, 2004; Horton et al., 2007, 2010; DeConto et al., 2008; Koenig et al., 2011). Other recent applications using the floating shelf component include PD07, PD09, PD12, Alley et al. (2007), Ackert et al. (2011), Fyke et al. (2011), Mackintosh et al. (2011), DeConto et al. (2012), Gomez et al. (2012) and Mukhopadhay et al. (2012). The model has participated in the ISMIP-HEINO/HOM, MISMIP and MISMIP3D intercomparisons (Pattyn et al., 2008, 2012a, b; Calov et al., 2010), and in the SeaRISE assessment project (Bindschadler et al., 2012).

For reference, new features added to the model since PD09 and described below are listed here:

- new parameterization of oceanic melt at base of floating ice;

- calving parameterization at floating ice edge;

- sub-grid fractional area of ice vs. ocean in cells at floating ice edge;

- oceanic melting at vertical ice faces;

- parameterization of shelf drag by sub-grid bathymetric pinning points;

- modified sub-grid application of Schoof (2007) grounding-line condition;

- optional simplifications in the combined SIA-SSA dynamics;
- adaptive reduction of model time step to avoid numerical instability;

- distribution of basal sliding coefficients deduced by a simple inverse method, described in PD12, and with the resulting pattern used here.

Two other features, not used in the applications below, will be described in future papers:

- sub-grid ice surface elevation interpolation and fractional area for calculation of surface mass balance at terrestrial ice margins (cf. van den Berg et al., 2006);

- improved numerics for nesting model capability in higher-resolution limited domains, with lateral boundary conditions from a previous continental run.

The bulk of this paper (Sects. 2.1 to 2.13) contains the model description, followed by an account of input datasets and climate forcing in Sect. 3. Section 4 presents results for modern Antarctica, where simulations at different resolutions are compared with observations. Section 5 presents paleoclimatic simulations of the last 5 Myrs, repeating those in PD09 with the new model version, and briefly discusses issues concerning the last deglaciation.

\section{Model description}

The model consists of diagnostic equations for ice velocities, and 3 prognostic equations for the temporal evolution of ice thickness, ice temperature, and bedrock deformation below the ice. Prescribed boundary fields are equilibrium bedrock topography and corresponding loading (modern rebounded ice-free state), unfrozen basal sliding coefficients, geothermal heat flux, and sea level. Monthly mean surface air temperatures and precipitation are either parameterized or provided from a climate model, in order to calculate annual surface mass balance and ice surface temperature (there is no seasonal cycle in the ice model itself). Sub-ice oceanic melting and shelf-edge calving are parameterized for floating ice shelves. A list of model symbols is provided in Table 1.

\subsection{Horizontal and vertical grids}

The ice sheet-shelf model uses a finite-difference ArakawaC grid (e.g., Rommelaere and Ritz, 1996), where horizontal velocities $(u, v)$ are calculated on separate grids staggered by half a grid box relative to ice thickness $(h)$, as shown in Fig. 1. The model code contains metric terms appropriate for Cartesian, Polar Stereographic, and Spherical Polar (longitude-latitude) grids, and also for flow lines with one horizontal dimension. Note however that for longitudelatitude grids, a rigorous derivation of the SSA equations introduces some spherical metric terms not in the current code, 
Table 1. Model symbols and nominal values.

\begin{tabular}{|c|c|}
\hline$x, y$ & Orthogonal horizontal coordinates (m) \\
\hline$z$ & Vertical elevation, increasing upwards from a flat reference plane $(\mathrm{m})$ \\
\hline$z^{\prime}$ & Vertical ice model coordinate ( 0 at ice surface, to 1 at base) \\
\hline$d x$ & Grid cell size, $\mathrm{x}$ or $\mathrm{y}$ directions $(\mathrm{m})$ \\
\hline$u, u_{\mathrm{i}}, u_{\mathrm{b}}$ & $\begin{array}{l}\text { Horizontal ice velocities in } \mathrm{x} \text { direction. } \\
u=\text { total, } u_{\mathrm{i}}=\text { internal deformation, } u_{b}=\text { basal }\left(\mathrm{m} \mathrm{a}^{-1}\right)\end{array}$ \\
\hline$v, v_{\mathrm{i}}, v_{\mathrm{b}}$ & $\begin{array}{l}\text { Horizontal ice velocities in y direction. } \\
v=\text { total, } v_{\mathrm{j}}=\text { internal deformation, } v_{b}=\text { basal }\left(\mathrm{m} \mathrm{a}^{-1}\right)\end{array}$ \\
\hline$u_{\mathrm{g}}, v_{\mathrm{g}}$ & Total ice velocities, $\mathrm{x}$ and $\mathrm{y}$ directions, across grounding line $\left(\mathrm{m} \mathrm{a}^{-1}\right)$ \\
\hline$q_{g}$ & Total ice flux, $\mathrm{x}$ or $\mathrm{y}$ direction, across grounding line $\left(\mathrm{m}^{2} \mathrm{a}^{-1}\right)$ \\
\hline$\dot{\varepsilon}_{i j}$ & Strain rate components $\left(\mathrm{a}^{-1}\right)$ \\
\hline$\dot{\varepsilon}$ & Effective strain rate, 2 nd invariant $\left(\mathrm{a}^{-1}\right)$ \\
\hline$\sigma_{i j}$ & Deviatoric stress components $(\mathrm{Pa})$ \\
\hline$\sigma$ & Effective stress, 2nd invariant $(\mathrm{Pa})$ \\
\hline$\mu$ & $1 / 2 \dot{\varepsilon}(1-n) / n\left(\mathrm{a}^{2 / 3}\right)$ \\
\hline $\mathrm{LHS}_{x}, \mathrm{LHS}_{y}$ & Left-hand sides of Eqs. 2a, 2b (Pa) \\
\hline$\tau_{x x}$ & Along-flow longitudinal stress at grounding line $(\mathrm{Pa})$ \\
\hline$\tau_{\mathrm{f}}$ & Non-buttressed longitudinal stress at grounding line $(\mathrm{Pa})$ \\
\hline$h$ & Ice thickness (m) \\
\hline$h_{\mathrm{S}}$ & Ice surface elevation $(\mathrm{m})$ \\
\hline$h_{\mathrm{b}}$ & Bedrock elevation (m) \\
\hline$h_{\mathrm{W}}$ & Ocean column thickness (m) \\
\hline$h^{\mathrm{eq}}$ & Ice thickness in bed-equilibrium state $(\mathrm{m})$ \\
\hline$h_{\mathrm{b}}^{\mathrm{eq}}$ & Bedrock elevation in bed-equilibrium state $(\mathrm{m})$ \\
\hline$h_{\mathrm{w}}^{\mathrm{eq}}$ & Ocean column thickness in bed-equilibrium state (m) \\
\hline$f_{\mathrm{e}}$ & Sub-grid cell-area fraction with ice ( 0 to1) \\
\hline$h_{\mathrm{e}}$ & Sub-grid ice thickness within cell-area fraction $f_{\mathrm{e}}(\mathrm{m})$ \\
\hline$h_{\mathrm{g}}$ & Ice thickness at grounding line $(\mathrm{m})$ \\
\hline$T$ & Ice temperature $\left({ }^{\circ} \mathrm{C}\right)$ \\
\hline$T_{\mathrm{m}}$ & Ice pressure-melting point $\left({ }^{\circ} \mathrm{C}\right)$ \\
\hline$T^{\prime}$ & Homologous ice temperature (relative to pressure-melting point) $\left({ }^{\circ} \mathrm{C}\right)$ \\
\hline$T_{\mathrm{b}}$ & Basal ice homologous temperature $\left({ }^{\circ} \mathrm{C}\right)$ \\
\hline$Q_{\mathrm{i}}$ & Internal deformational heating $\left(\mathrm{J} \mathrm{a}^{-1} \mathrm{~m}^{-3}\right)$ \\
\hline$Q_{\mathrm{b}}$ & Basal shear heating $\left(\mathrm{J} \mathrm{a}^{-1} \mathrm{~m}^{-2}\right)$ \\
\hline$A$ & Ice rheological coefficient $\left(\mathrm{a}^{-1} \mathrm{~Pa}^{-3}\right)$ \\
\hline$n$ & Ice rheological exponent (3) \\
\hline$E$ & Ice flow enhancement factor ( 1 for SIA, 0.3 for SSA) \\
\hline
\end{tabular}

which would need to be modified in order to properly treat global-scale floating ice (Tziperman et al., 2012).

The ice model uses a vertical coordinate $z^{\prime}$ running from 0 at the ice surface to 1 at the ice base:

$z^{\prime}=\left(h_{s}-z\right) / h$

where $h_{\mathrm{s}}$ is ice surface elevation and $h$ is ice thickness. The vertical grid has 10 uneven layers, more closely spaced near the top and bottom. Ice temperatures and horizontal velocities are defined at the mid point of each layer.

\subsection{Ice velocities}

A combination of the scaled equations for vertical shearing (" $\partial u / \partial z$ ", shallow ice approximation, SIA) and horizon- tal longitudinal stretching (" $\partial u / \partial x$ ", shallow shelf approximation, SSA) is used, similarly to several previous hybrid models mentioned in Sect. 1. The combination is heuristic because neither scaling is accurate where both shearing and stretching are significant (streaming and grounding zones). Nevertheless, with the additional imposition of Schoof's (2007) grounding-line flux condition described below, reasonable results are obtained in idealized intercomparison tests (Pattyn et al., 2012a, b). The numerics are simple enough to allow long-term $O\left(10^{7}\right)$ year continental-scale runs. Recent modeling progress using full-Stokes or higherorder flow equations on fine or adaptive grids rigorously include these processes (e.g., Morlighem et al., 2010; Seddik et al., 2012), but require considerably more computer time, and for now are limited to shorter time or smaller spatial scales. 
Table 1. Continued.

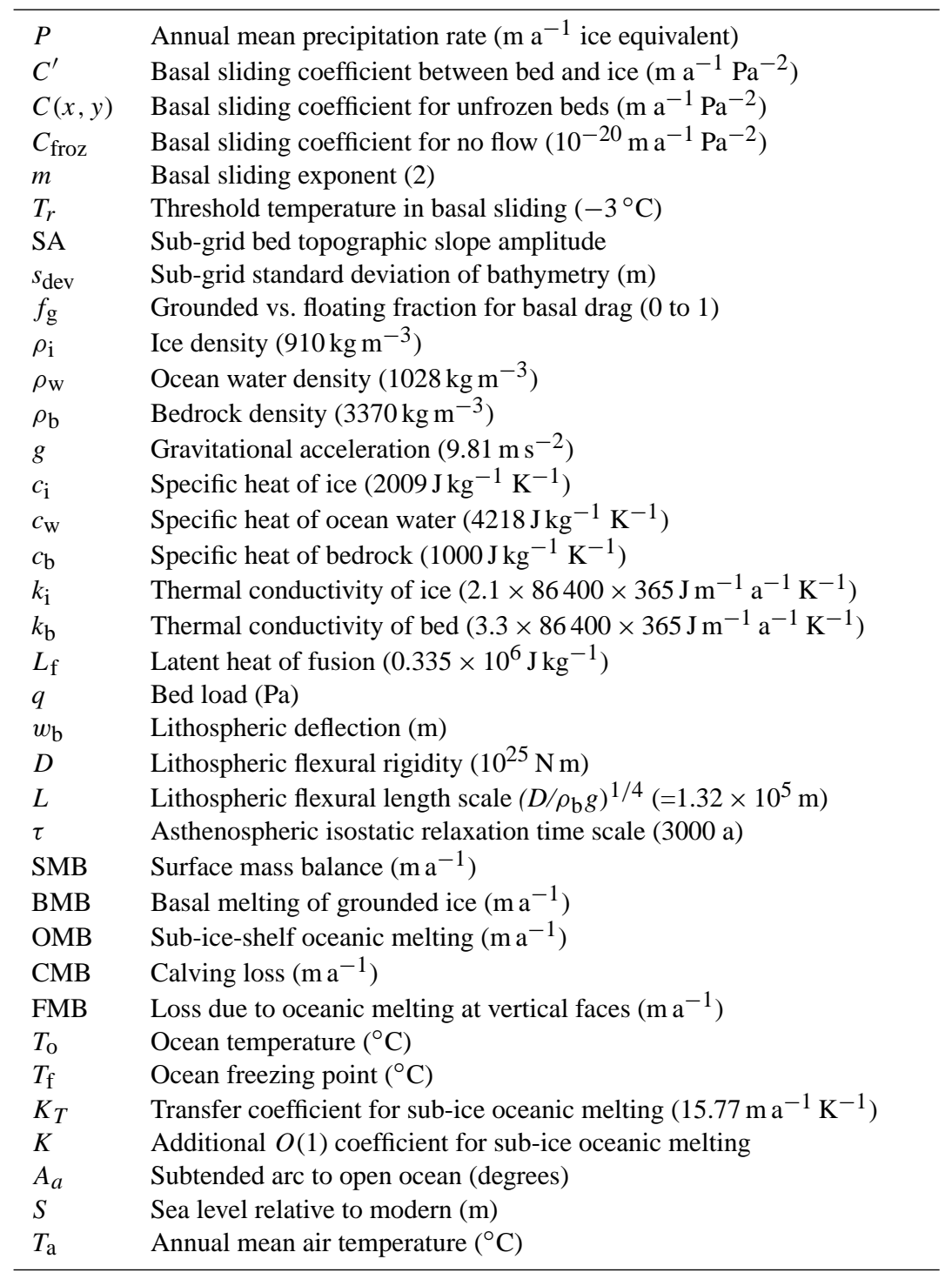

As described in PD07 and PD09, the SIA and SSA equations are combined as follows:

1. In the expressions for effective viscosities, SIA's $\partial u / \partial z$ shear-softening terms are included in the viscosity for SSA, and SSA's $\partial u / \partial x$ terms are included in the viscosity for SIA.

2. The SSA equations solve for depth-averaged total velocity. But in the SSA basal stress terms, a distinction is made between depth-averaged and basal velocity, with the difference being the vertical mean of the SIA shear flow.

3. The driving stress in the SIA equations is reduced by the gradient of the longitudinal stress from the SSA equations acting on the column above each level.
These steps require an iteration between the SSA and SIA solutions, as described below. Goldberg (2011) takes essentially the same steps, and discusses the relationship with Schoof and Hindmarsh (2010). Cartesian coordinates are used in the equations here, although metric terms are included in the model code to handle other grids (but see Sect. 2.1). All symbols are listed in Table 1. The following presentation is very similar to PD07 Appendix A (noting an erroneous factor of 2 in their Eq. A2a, b).

Writing Cartesian horizontal ice velocities as $u(x, y, z)$ and $v(x, y, z)$, define the basal ice velocity $u_{\mathrm{b}}(x, y)=u\left(x, y, z_{b}\right)$, and the internal shearing ice velocity $u_{\mathrm{i}}(x, y, z)=u-u_{\mathrm{b}}$, so that $u_{\mathrm{i}}\left(x, y, z_{b}\right)=0$. Denoting vertical averages through the ice column with a bar, then $\bar{u}=u_{\mathrm{b}}+\bar{u}_{i}$ and similarly for $\bar{v}, v_{\mathrm{b}}$ and $\bar{v}_{i}$. The SIA-like internal shear equations for 


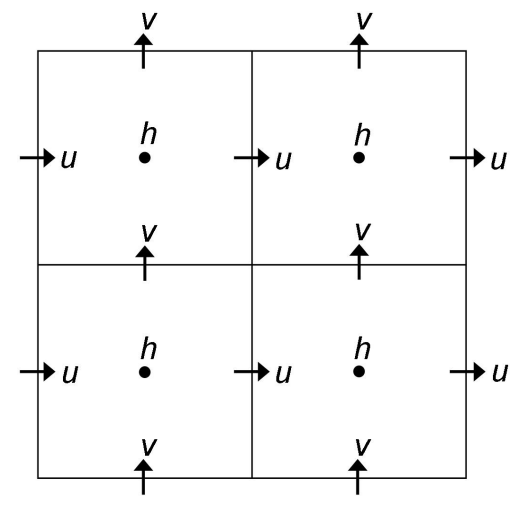

Fig. 1. Finite-difference staggered grids in the ice sheet-shelf model. $h$ denotes the centers of h-grid boxes, where ice thickness, ice temperatures, and bedrock elevations are calculated. $u$ and $v$ denote the staggered grid points where horizontal velocity components are calculated.

$u_{\mathrm{i}}(x, y, z)$ and $v_{\mathrm{i}}(x, y, z)$ are

$\frac{\partial u_{i}}{\partial z}=2 A\left[\sigma_{x z}^{2}+\sigma_{y z}^{2}+\sigma_{x x}^{2}+\sigma_{y y}^{2}+\sigma_{x y}^{2}+\sigma_{x x} \sigma_{y y}\right]^{\frac{n-1}{2}} \sigma_{x z}$

$\frac{\partial v_{i}}{\partial z}=2 A\left[\sigma_{x z}^{2}+\sigma_{y z}^{2}+\sigma_{x x}^{2}+\sigma_{y y}^{2}+\sigma_{x y}^{2}+\sigma_{x x} \sigma_{y y}\right]^{\frac{n-1}{2}} \sigma_{y z}$

where $\sigma_{i j}$ are deviatoric stresses given below (Cuffey and Paterson, 2010). The SSA-like horizontal stretching equations for $\bar{u}(x, y)$ and $\bar{v}(x, y)$ are

$\frac{\partial}{\partial x}\left[\frac{2 \mu h}{\bar{A}^{1 / n}}\left(2 \frac{\partial \bar{u}}{\partial x}+\frac{\partial \bar{v}}{\partial y}\right)\right]+\frac{\partial}{\partial y}\left[\frac{\mu h}{\bar{A}^{1 / n}}\left(\frac{\partial \bar{u}}{\partial y}+\frac{\partial \bar{v}}{\partial x}\right)\right]$

$=\rho_{i} g h \frac{\partial h_{s}}{\partial x}+\frac{f_{g}}{C^{\prime 1 / m}}\left|u_{\mathrm{b}}^{2}+v_{\mathrm{b}}^{2}\right|^{\frac{1-m}{2 m}} u_{\mathrm{b}}$

$\frac{\partial}{\partial y}\left[\frac{2 \mu h}{\bar{A}^{1 / n}}\left(2 \frac{\partial \bar{v}}{\partial y}+\frac{\partial \bar{u}}{\partial x}\right)\right]+\frac{\partial}{\partial x}\left[\frac{\mu h}{\bar{A}^{1 / n}}\left(\frac{\partial \bar{u}}{\partial y}+\frac{\partial \bar{v}}{\partial x}\right)\right]$

$=\rho_{i} g h \frac{\partial h_{s}}{\partial y}+\frac{f_{g}}{C^{\prime 1 / m}}\left|u_{\mathrm{b}}^{2}+v_{\mathrm{b}}^{2}\right|^{\frac{1-m}{2 m}} v_{\mathrm{b}}$

Equation ( $2 \mathrm{a}, \mathrm{b})$ and their horizontal boundary conditions for unconfined ice shelves are derived for instance in Morland (1982) and MacAyeal (1996). In Eqs. (2a, b), $u_{\mathrm{b}}=$ $\bar{u}-\bar{u}_{i}$ and $v_{\mathrm{b}}=\bar{v}-\bar{v}_{i}$ where $\bar{u}_{i}$ and $\bar{v}_{i}$ are obtained from vertical integrations of (1a, b) (e.g., Ritz et al., 1997).

In the zero-order shallow ice approximation, the vertical shear stress $\left(\sigma_{x z}, \sigma_{y z}\right)$ in Eqs. $(1 \mathrm{a}, \mathrm{b})$ would be balanced only by the hydrostatic driving force $-\rho_{\mathrm{i}} g\left(h_{\mathrm{s}}-z\right)$ $\left(\partial h_{\mathrm{s}} / \partial x, \partial h_{\mathrm{s}} / \partial y\right)$ acting on the ice column above level $z$. Here, horizontal stretching forces are included in this force balance (Hubbard, 1999, 2006; Marshall et al., 2005), so that

$$
\begin{gathered}
\sigma_{x z}=-\left(\rho_{i} g h \frac{\partial h_{s}}{\partial x}-\mathrm{LHS}_{x}\right)\left(\frac{h_{s}-z}{h}\right), \\
\sigma_{y z}=-\left(\rho_{i} g h \frac{\partial h_{s}}{\partial y}-\mathrm{LHS}_{y}\right)\left(\frac{h_{s}-z}{h}\right)
\end{gathered}
$$

where $\mathrm{LHS}_{x}$ and LHS $y$ are the left-hand sides of Eqs. (2a) and (2b), respectively. Because horizontal stretching forces are taken to be vertically uniform and the terms in Eq. (2) are forces on the entire ice thickness, their effect on the ice column above level $z$ is scaled by $\left(h_{\mathrm{s}}-z\right) / h$ in Eq. (3).

Inclusion of the strain softening terms in Eqs. (1) and (2) due to each other's flow (i.e., $\sigma_{x x}, \sigma_{y y}, \sigma_{x y}$ in Eq. (1), $\partial u_{\mathrm{i}} / \partial z$ and $\partial v_{\mathrm{i}} / \partial z$ in $\mu$ in Eq. (2)), requires manipulation of the constitutive relation for ice rheology. In Eq. (2),

$\mu \equiv \frac{1}{2}\left(\dot{\varepsilon}^{2}\right)^{\frac{1-n}{2 n}}$,

and $\bar{A}=\int \mathrm{A} \mathrm{dz} / h$ is the vertical mean of the Arrhenius temperature-dependent coefficient in the constitutive relation

$\dot{\varepsilon}_{i j}=A(T)\left(\sigma^{2}\right)^{\frac{n-1}{2}} \sigma_{i j}$ or equivalently $\dot{\varepsilon}_{i j}=A(T)^{\frac{1}{n}}\left(\dot{\varepsilon}^{2}\right)^{\frac{n-1}{2 n}} \sigma_{i j}$

where $\dot{\varepsilon}_{i j}$ are strain rates, $\sigma_{i j}$ are deviatoric stresses, and $\dot{\varepsilon}$ and $\sigma$ are the second invariants of their respective tensors. The latter are defined by $\dot{\varepsilon}^{2} \equiv \sum_{i j} \frac{1}{2} \dot{\varepsilon}_{i j} \dot{\varepsilon}_{i j}$ and $\sigma^{2} \equiv$ $\sum_{i j} \frac{1}{2} \sigma_{i j} \sigma_{i j}$. The relationship

$\dot{\varepsilon}^{2} \approx\left(\frac{\partial \bar{u}}{\partial x}\right)^{2}+\left(\frac{\partial \bar{v}}{\partial y}\right)^{2}+\frac{\partial \bar{u}}{\partial x} \frac{\partial \bar{v}}{\partial y}$

$+\frac{1}{4}\left(\frac{\partial \bar{u}}{\partial x}+\frac{\partial \bar{v}}{\partial y}\right)^{2}+\frac{1}{4}\left(\overline{\frac{\partial u_{i}}{\partial z}}\right)^{2}+\frac{1}{4}\left(\overline{\frac{\partial v_{i}}{\partial z}}\right)^{2}$

is used to set $\mu$ in Eq. (2), and follows using

$$
\begin{aligned}
& \dot{\varepsilon}^{2}=\dot{\varepsilon}_{x x}^{2}+\dot{\varepsilon}_{x x}^{2}+\dot{\varepsilon}_{x x} \dot{\varepsilon}_{y y}+\dot{\varepsilon}_{x y}^{2}+\dot{\varepsilon}_{x z}^{2}+\dot{\varepsilon}_{y z}^{2}, \\
& \dot{\varepsilon}_{x x}+\dot{\varepsilon}_{y y}+\dot{\varepsilon}_{z z}=0, \\
& \dot{\varepsilon}_{x x}=\frac{\partial \bar{u}}{\partial x}, \quad \dot{\varepsilon}_{y y}=\frac{\partial \bar{v}}{\partial y}, \quad \dot{\varepsilon}_{x y}=\frac{1}{2}\left(\frac{\partial \bar{u}}{\partial y}+\frac{\partial \bar{v}}{\partial x}\right), \\
& \dot{\varepsilon}_{x z} \approx \frac{1}{2} \frac{\overline{\partial u}}{\partial z}, \quad \dot{\varepsilon}_{y z} \approx \frac{1}{2} \frac{\overline{\partial v_{i}}}{\partial z} .
\end{aligned}
$$

The corresponding expression for $\sigma^{2}$ is used in Eq. (1), and the purely horizontal components are obtained in our numerical procedure from

$$
\begin{aligned}
& \sigma_{x x}^{2}+\sigma_{y y}^{2}+\sigma_{x y}^{2}+\sigma_{x x} \sigma_{y y} \\
& =\left(\frac{2 \mu}{\bar{A}^{1 / n}}\right)^{2}\left[\left(\frac{\partial \bar{u}}{\partial x}\right)^{2}+\left(\frac{\partial \bar{v}}{\partial y}\right)^{2}+\frac{\partial \bar{u}}{\partial x} \frac{\partial \bar{v}}{\partial y}+\frac{1}{4}\left(\frac{\partial \bar{u}}{\partial x}+\frac{\partial \bar{v}}{\partial y}\right)^{2}\right]
\end{aligned}
$$

The basal sliding relation used on the right-hand sides of Eqs. (2a) and (2b) for grounded ice is $\tilde{u}_{\mathrm{b}}=C^{\prime}\left|\tau_{\mathrm{b}}\right|^{m-1} \tilde{\tau}_{\mathrm{b}}$ (see Sect. 2.4), or equivalently $\tilde{\tau}_{\mathrm{b}}=C^{\prime-\frac{1}{m}}\left|u_{\mathrm{b}}\right|^{\frac{1-m}{m}} \tilde{u}_{\mathrm{b}}$, where $\tilde{\tau}_{\mathrm{b}}$ is basal stress. Where ice is grounded, i.e., where $\rho_{w}\left(S-h_{\mathrm{b}}\right)<$ $\rho_{i} h$ or the ocean has no access (held back by intervening thicker ice or higher land), then $f_{\mathrm{g}}=1$ in the sliding terms, and the ice surface elevation $h_{\mathrm{s}}=h+h_{\mathrm{b}}$. Where ice is floating, i.e., $\rho_{w}\left(S-h_{\mathrm{b}}\right)>\rho_{i} h$ and the ocean has access, then $f_{\mathrm{g}}$ 
$=0$ and $h_{\mathrm{s}}=S+h\left(1-\rho_{\mathrm{i}} / \rho_{\mathrm{w}}\right) .\left(S\right.$ here is sea level, and $h_{\mathrm{b}}$ is bed elevation).

At each time step, an outer iteration is performed that solves for SSA and SIA velocities, updates ice thicknesses for half of the time step, and re-solves the velocities using the new ice thicknesses, i.e., a second-order Runge-Kutta method. In the solution of Eq. (2) for SSA velocities, a standard (Picard) inner iteration is performed to account for the non-linear dependence of $\mu$ and basal sliding on the velocities in Eqs. (2), (4) and (6). The outer iteration converges naturally to the appropriate scaling of SSA vs. SIA flow, depending on the magnitude of the basal sliding coefficient. Usually the flow is either almost all vertical shear, with basal drag balancing the driving stress and with negligible stretching, or is almost all longitudinal stretching which balances the driving stress, with small or no basal drag and negligible internal shear. For a fairly narrow range of sliding coefficients, significant amounts of both flow types co-exist.

In each pass of the outer iteration, the SSA Eqs. (2a, b) are solved first, using a sparse matrix method, or optionally, successive over-relaxation (SOR) (or a tridiagonal matrix solution for 1-D flow-line problems). Then the ice-thickness advection equation (Sect. 2.6) is time-stepped accounting for both SSA and SIA flow. Ice advection due to SIA is performed time implicitly, with the vertically averaged SIA flow given from Eqs. (1) and (3) and using time-implicit linearized Newton-Raphson contributions from all $h$ and $\partial h_{\mathrm{s}} / \partial x$ terms (as in earlier SIA-only model versions; DeConto and Pollard, 2003). Centered ice thicknesses are used for the SIA advection, whereas the time-explicit SSA advection uses upstream ice thicknesses for stability (in Eq. 14 below). An Alternating Direction Implicit (ADI) scheme is used for $\mathrm{x}$ vs. $\mathrm{y}$ directions (Mahaffy, 1976). A CFL-based maximum speed limit on horizontal velocities can be imposed for stability. No ice advection is allowed out of grid cells with sub-grid areal fraction $f_{\mathrm{e}}<1$ (which occurs only for cells at the edge of floating ice shelves, see Sect. 2.9).

CPU time in the model is dominated by the SparseMatrix (or SOR) solutions of the SSA equations. As described in PD09, a considerable reduction in CPU time can be achieved by restricting the full SSA+SIA iterative procedure to grid points with mid-to-high values of the basal sliding coefficient, $C(x, y) \geq 10^{-8} \mathrm{~m} \mathrm{a}^{-1} \mathrm{~Pa}^{-2}$ (see PD12). This range includes all fast streaming regions underlain with deformable sediment $\left(\sim 10^{-5}\right)$. For lower $C(x, y)$ values $<10^{-8}$ (including hard bedrock, $\sim 10^{-10}$ ), the full procedure yields virtually $100 \%$ shearing (SIA) flow anyway. At the latter points, advection by internal shear deformation $\left(\bar{u}_{i}, \bar{v}_{i}\right)$, and basal sliding $\left(u_{\mathrm{b}}, v_{\mathrm{b}}\right)$ are both modeled by standard SIA dynamics. At full SSA+SIA points with $C(x, y)$ $\geq 10^{-8}$, advection by internal shear deformation, basal and horizontal stretching are all included in the coupled solution of Eqs. (1) and (2). Tests show that results are essentially unchanged from those with the full SSA+SIA iteration performed at all locations.
In intermediate model versions, some simplifications were tried in the coupling dynamics such as neglecting the strain softening cross-terms in Eqs. (1) and (6), which reduced CPU time modestly with only slight effects on the results. Some of these simplifications were used for the figures shown below; however, the most complete and current model version is described above.

\subsection{Grounding-line flux condition}

Flow-line tests with hybrid or higher-order models show that in order to capture grounding-line migration accurately, it is necessary either to resolve the grounding-zone boundary layer at very fine resolution (Schoof, 2007; Gladstone et al., 2010a, 2012a; Pattyn et al., 2012a), or to apply an analytic constraint on the flux across the grounding line. The latter approach is used here, with flux $q_{g}$ across model grounding lines parameterized as in Schoof (2007, his Eq. 29):

$q_{g}=\left(\frac{\bar{A}\left(\rho_{i} g\right)^{n+1}\left(1-\rho_{i} / \rho_{w}\right)^{n}}{4^{n} C_{s}}\right)^{\frac{1}{m_{s}+1}}\left(\frac{\tau_{x x}}{\tau_{f}}\right)^{\frac{n}{m_{s}+1}}\left(h_{g}^{\frac{m_{s}+n+3}{m_{s}+1}}\right)$

This yields the vertically averaged velocity $u_{\mathrm{g}}=q_{g} / h_{g}$ where $h_{\mathrm{g}}$ is the ice thickness at the grounding line. The middle term in Eq. (8) accounts for back stress at the grounding line due to buttressing by downstream islands, pinning points or side-shear, where $\tau_{x x}$ is the longitudinal stress just downstream of the grounding line, calculated from the viscosity and strains in a preliminary SSA solution with no Schoof constraints. The free stress $\tau_{\mathrm{f}}$ is the same quantity in the absence of any buttressing, given by $0.5 \rho_{\mathrm{i}} g h_{\mathrm{g}}\left(1-\rho_{\mathrm{i}} / \rho_{\mathrm{w}}\right)$ (cf. Goldberg et al., 2009; Gagliardini et al., 2010). $\bar{A}$ is the depth-averaged ice rheological coefficient and $n$ is the GlenLaw exponent, $C_{S}$ is Schoof's (2007) basal sliding coefficient and $m_{s}$ the basal sliding exponent, corresponding here to $C^{-1 / m}$ and $1 / m$, due to the reversed form of the basal sliding law. $\rho_{\mathrm{i}}$ and $\rho_{\mathrm{w}}$ are densities of ice and ocean water respectively, and $g$ is the gravitational acceleration. $h_{\mathrm{g}}$ is interpolated in space by first estimating the sub-grid position of the grounding line between the two surrounding floating and grounded h-grid points. This is done by linearly interpolating height above flotation between those two points to where it is zero, linearly interpolating bedrock elevation to that location, and then simply computing the flotation thickness of ice for that bedrock elevation and current sea level (equivalent to LI in Gladstone et al., 2010b).

The velocity $u_{\mathrm{g}}$ is calculated at the grounding-line points on the u-grid, i.e., those with floating ice in one adjacent (left or right) h-grid box and grounded ice in the other (and similarly for $v_{\mathrm{g}}$ on the v-grid). These velocities are imposed as an internal boundary condition for the flow equations, in effect overriding the large-scale velocity solution at the grounding line. This procedure only considers one-dimensional dynamics perpendicular to the grounding line, as in the 1-D flowline analysis in Schoof (2007). It works naturally with the 
staggered C-grid (Sect. 2.7), where the grounding line is a continuous series of perpendicular segments of u-direction or v-direction interfaces between h-grid boxes, and $u_{\mathrm{g}}\left(v_{\mathrm{g}}\right)$ velocities flow across interfaces running through u-grid ( $\mathrm{v}-$ grid) points. Equations (8-9) and the discussion in this section applies equally to the y direction, with $v_{\mathrm{g}}$ and $\tau_{y y}$ instead of $u_{\mathrm{g}}$ and $\tau_{x x}$. Note that spatial gradients of quantities parallel to the grounding line, which are not included in Schoof's (2007) flow-line derivation of Eq. (8), are neglected here (Katz and Worster, 2010; Gudmundsson et al., 2012; Pattyn et al., 2012b).

We have tested this method of solution in many idealized 1-D flow-line tests, similar to those in Schoof (2007). Our goal was to achieve the same grounding-migration results using a coarse grid ( $\sim 10$ to $40 \mathrm{~km}$ ) with those using very finegrids $(\sim 0.1 \mathrm{~km})$. For coarse grids, we find that it is necessary to impose Eq. (8) as a grounding-line boundary condition. Also for coarse grids we find that an additional rule is necessary, because the outer-solution structure of the grounding zone is not fully captured by the grid:

If the flux $q_{g}$ from Eq. (8) is greater than the large-scale shelf-equation's flux $q_{m}$ at the grounding line, then $u_{\mathrm{g}}\left(=q_{g} / h_{g}\right)$ is imposed exactly at the u-grid grounding-line point; conversely if $q_{g}<q_{m}$, then $u_{g}$ is imposed one u-grid box downstream of the grounding-line point. The former is usually associated with grounding-line retreat, and the latter usually with grounding-line advance.

When converting the grounding-line flux $q_{g}$ from Eq. (8) to a velocity $\left(u_{\mathrm{g}}\right)$, it is important to divide by the ice thickness (called $h_{\mathrm{g}}$ above) that will effectively be used at the relevant point in Eq. (9) in the finite-difference numerics of the ice advection equation. Then the model's flux at that point will be exactly that from Eq. (8). In simple equilibrated flow-line tests, this means that the model flux equals the net surface mass balance upstream from the grounding line, an important property of analytic solutions. This yields good agreement with analytic solutions including hysteresis in MISMIP-like tests, using grid sizes of $\sim 5$ to several $10 \mathrm{~s} \mathrm{~km}$ (Pollard and DeConto, 2011; Docquier et al., 2011; Pattyn et al., 2012a). The agreement can be made almost exact by adjusting the flux $q_{g}$ for the increment in surface mass balance between the actual grounding line and the point where Eq. (9) is applied, as illustrated in Fig. 2. The analytic solutions in turn agree well with full-Stokes model results, at least in steadystate non-transient situations (Drouet et al., 2011; Pattyn et al., 2012a).

In efforts to minimize single-cell dithering in some idealized tests, i.e., flipping back and forth between upstream and downstream points in Eq. (9), two further measures were taken:

i. An initial SSA solution is done at each time step, without any imposed flux from Eq. (8), to calculate the large-scale flux that is compared to the imposed flux in Eq. (9). Previously the large-scale flux was estimated by local finite differences.

ii. Values of the imposed velocities from Eq. (8) are calculated for both upstream and downstream points of the grounding line, and these are imposed in the flow equations with weights between 0 and 1 depending on how much (and with what sign) the large-scale flux differs from the imposed flux as in Eq. (8).

These measures had little effect on the dithering in flow-line tests, but fortunately no associated degradation of large-scale results has been detected.

\subsection{Basal sliding coefficients}

Basal sliding is treated similarly to PD09 by a standard drag law (Cuffey and Paterson, 2010; Pattyn, 2010; Le Brocq et al., 2011)

$\tilde{u}_{\mathrm{b}}=C^{\prime}\left|\tau_{\mathrm{b}}\right|^{m-1} \tilde{\tau}_{\mathrm{b}}$

where $\tilde{u}_{\mathrm{b}}$ is basal sliding velocity, $\tilde{\tau}_{\mathrm{b}}$ is basal stress, and $m=2$ as in Sect. 2.2. As described in PD12, the sliding coefficient $C^{\prime}$ depends on homologous basal temperature, implicitly representing basal hydrology:

$C^{\prime}=(1-r) C_{\text {froz }}+r C(x, y)$

where $r=\max \left[0, \min \left[1,\left(T_{\mathrm{b}}+3\right) / 3\right]\right]$

where $C(x, y)$ is the full sliding coefficient, and $C_{\text {froz }}=$ $10^{-20} \mathrm{ma}^{-1} \mathrm{~Pa}^{-2}$ (which is small enough to prevent any discernible sliding, but is not exactly zero to avoid divide-byzero exceptions in the numerics). $T_{\mathrm{b}}\left({ }^{\circ} \mathrm{C}\right)$ is the homologous basal temperature, i.e., relative to the pressure melt point $T_{\mathrm{m}}=-.000866 h$ where $h$ is ice thickness (m). There is no sliding below the threshold homologous temperature $\left(-3^{\circ} \mathrm{C}\right)$, ramping up linearly to full sliding at the melt point.

$C(x, y)$ is a specified basal sliding coefficient representing intrinsic bed properties. In PD09 it was twovalued, depending on whether the modern rebounded Antarctic bedrock is above or below sea level: if above, $C(x, y)=10^{-10} \mathrm{~m} \mathrm{a}^{-1} \mathrm{~Pa}^{-2}$ representing hard bedrock (mainly EAIS), and if below, $C(x, y)=10^{-6} \mathrm{~m} \mathrm{a}^{-1} \mathrm{~Pa}^{-2}$ representing deformable sediment (mainly WAIS) (e.g., Studinger et al., 2001) shown in Fig. 3a. In PD12, a simple inverse method is used that attempts to deduce the real distribution of $C(x, y)$ under modern Antarctica, constrained to the range $10^{-10}$ to $10^{-5} \mathrm{~m} \mathrm{a}^{-1} \mathrm{~Pa}^{-2}$.

In PD12, modern Antarctic results are further improved by adding a dependence on sub-grid bedrock relief, that allows more sliding across major mountain ranges, presumably in deep and warmer valley troughs not resolved by the model grid. Without this addition, basal ice is often completely frozen over mountain ranges, and insufficient crossrange flow causes surface elevations to be too high (PD12). 
(a)

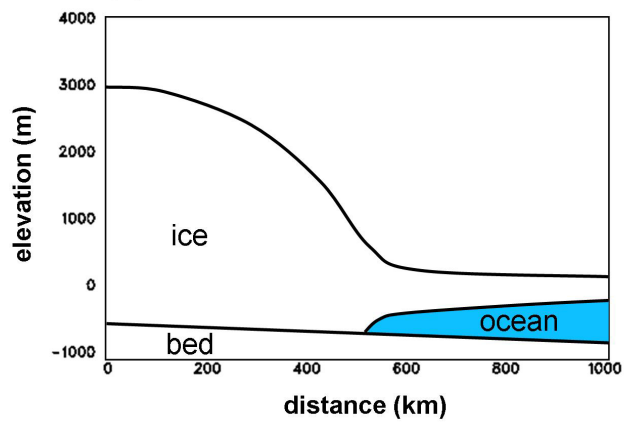

(b)

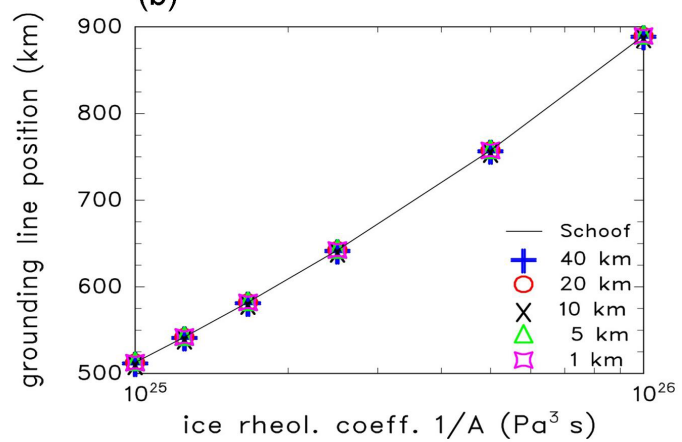

(c)

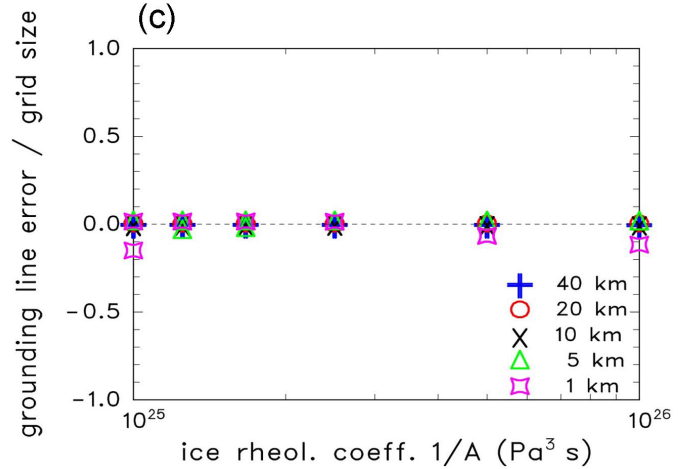

Fig. 2. Idealized flow-line model tests, similar to basic MISMIP (Pattyn et al., 2012), with uniform surface mass balance, an ice divide at the left-hand boundary, a forward-sloping bed into ocean, and using surface-mass-balance increments to $q_{g}$ (see text). (a) Geometry showing sloping bed and ice sheet profiles. (b) Model equilibrated grounding-line positions vs. 1/rheological coefficient $A$, for various grid sizes and initial states. Solid line shows the analytic solution (Schoof, 2007). (c) As (b) except showing model error (model minus analytic grounding-line position), divided by grid size.
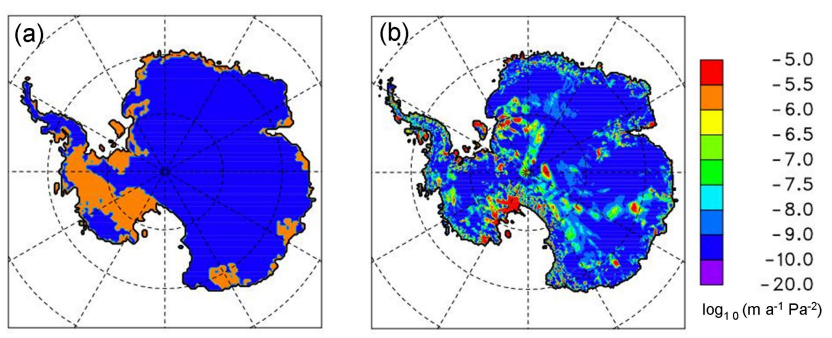

Fig. 3. Basal sliding coefficients $C(x, y)$. (a) Simple twovalued map: blue $=10^{-10} \mathrm{ma}^{-1} \mathrm{~Pa}^{-2}$ (hard bedrock) where modern ice-free rebounded modern bed is above sea level, orange $=10^{-6} \mathrm{ma}^{-1} \mathrm{~Pa}^{-2}$ (deformable sediment) where below (PD09). (b) Deduced from inverse-method fitting to modern ice surface elevations (PD12, with basal temperature and bedrock relief affecting sliding), $20 \mathrm{~km}$ resolution.

We attempt to parameterize this sub-grid process by modifying the width of the basal-temperature ramp in Eq. (11), replacing it by

$C^{\prime}=(1-r) C_{\text {froz }}+r C(x, y)$

where $r=\max \left[0, \min \left[1,\left(T_{\mathrm{b}}-T_{r}\right) /\left(-T_{r}\right)\right]\right]$ and

$T_{r}=-3-500 \max [\mathrm{SA}-.02,0]-.05 \max \left[h_{\mathrm{b}}^{\mathrm{eq}}-1700,0\right](12 \mathrm{~b})$

where SA is the mean sub-grid slope amplitude computed by averaging the bed slopes in the 5-km ALBMAP dataset (Le Brocq et al., 2010) within each model grid box. This quantity was also used by Marshall et al. (1996) in another context. $h_{\mathrm{b}}^{\mathrm{eq}}$ is the ice-free, isostatically rebounded, 9-pointsmoothed bed elevation on the model grid, used to mimic SA in data-sparse regions (PD12). The values of the constants are discussed in PD12. Whitehouse et al. (2012) apply a similar increase in sliding coefficient over mountainous terrain, for much the same reasons. Equation (12) and the associated inverse-derived $C(x, y)$ distribution (Fig. $3 b$ ) are used in the simulations below.

For grid points where the full SSA+SIA iteration is performed (Sect. 2.2), $C^{\prime}$ and $u_{\mathrm{b}}$ enter in the right-hand side of the SSA in Eq. (2), where Eq. (10) is inverted to give $\tau_{\mathrm{b}}$ as a function of $u_{\mathrm{b}}$, and $u_{\mathrm{b}}$ is treated time explicitly in the stepping of the ice thickness as in Eq. (14). For points where just the SIA equation is used as discussed in Sects. 2.2, Eq. (10) is treated time implicitly, with $\tau_{\mathrm{b}}$ equal to the driving stress $\left(\rho_{\mathrm{i}} g h \partial h_{s} / \partial x\right)$, and with linearized Newton-Raphson 

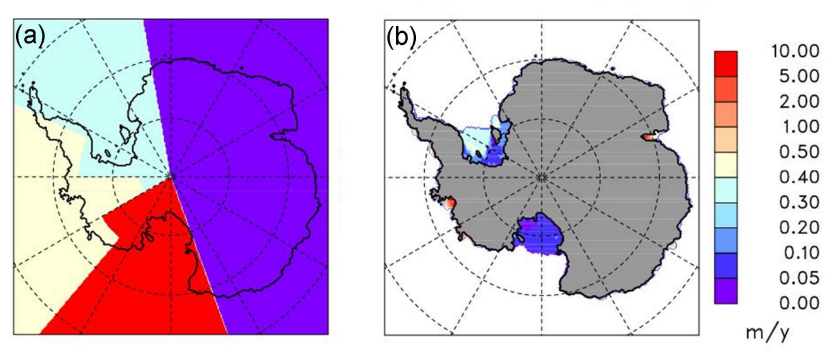

Fig. 4. (a) Sectors used in sub-ice oceanic melt parameterization. Yellow: Amundsen and Bellingshausen Seas, and western Peninsula. Blue: Weddell embayment. Purple: East Antarctica. Red: Ross embayment. (b) Sub-ice oceanic melt rates $\left(\mathrm{m} \mathrm{a}^{-1}\right)$ in modern simulation with $20 \mathrm{~km}$ resolution. The average values for each major shelf are reasonable (Nicholls et al., 2009; Olbers and Hellmer, 2010; Dinniman et al., 2011), although somewhat lower for the Ross. Rates are noticeably larger nearer the grounding lines due to the depth dependence of the freezing point $T_{\mathrm{f}}$ in Eq. (17), especially in Pine Island and Prydz Bays, but not noticeably for the flatter Ross Ice Shelf.

contributions from Eq. (10) in the same way as for internal shearing in Eq. (1).

\subsection{Sub-grid pinning points}

Under the major ice shelves, there may be sub-grid pinning points due to small bathymetric rises scraping the bottom of the ice, especially near the grounding line, that are unresolved by the model grid. This is parameterized simply in terms of the standard deviation of observed bathymetry within each model cell. The fractional area $f_{\mathrm{g}}$ of ice in contact with sub-grid bathymetric high spots is

$f_{g}=0.5 \max \left[0,1-\frac{h_{w}}{s_{\mathrm{dev}}}\right]$

where $h_{\mathrm{w}}$ is the thickness of the ocean column between the cell-mean bedrock and ice base, and $s_{\mathrm{dev}}$ is the standard deviation of the observed bed elevations (ALBMAP, $5 \mathrm{~km}$, Le Brocq et al., 2010) within the cell. For 20 to $40 \mathrm{~km}$ grids, $s_{\mathrm{dev}}$ is typically smaller than $\sim 50 \mathrm{~m}$ under the Ross and much of the Weddell and Amery ice shelves, but up to to a few 100s $\mathrm{m}$ in isolated patches of the Weddell, Lambert, and much of Pine Island Bay.

$f_{\mathrm{g}}$ here is identical to the $f_{\mathrm{g}}$ in Eqs. (2a, $\mathrm{b}$ ), and modifies the basal stress for the cell. Instead of no drag $\left(f_{\mathrm{g}}=0\right.$, freely floating ice), the value from Eq. (13) is used, increasing the basal stress to $f_{\mathrm{g}}$ times the amount for $100 \%$ basal contact.

In effect, this augments the overall drag on the ice shelf in addition to side drag, which is transmitted upstream within the SSA equations, increasing buttressing and reducing ice flux across the grounding line, i.e., making $\tau_{x x}$ less positive and reducing $q_{g}$ in Eq. (8). The extent and importance of small-scale pinning is somewhat speculative, and deserves more study, observationally by examination of surface fea- tures or improved bathymetry (Horgan and Anandakrishnan, 2006; Fricker et al., 2009; Hulbe et al., 2010; Timmermann et al., 2010), and by modeling such as Favier et al. (2012).

\subsection{Ice thickness}

$\frac{\partial h}{\partial t}=-\frac{\partial(\bar{u} h)}{\partial x}-\frac{\partial(\bar{v} h)}{\partial y}$

$+\mathrm{SMB}-\mathrm{BMB}-\mathrm{OMB}-\mathrm{CMB}-\mathrm{FMB}$

where $\mathrm{SMB}=$ surface mass balance, $\mathrm{BMB}=$ basal melting (if grounded), $\mathrm{OMB}=$ oceanic sub-ice melting or freezing (if floating), $\mathrm{CMB}=$ calving loss (floating edge), and $\mathrm{FMB}=$ face melt loss (floating or tidewater vertical face).

The time stepping of the ice thickness equation is done as part of the iterative solution of ice velocities as described in Sect. 2.2. The treatments of the various local ice gains or losses (SMB, etc) are described in later sections.

\subsection{Ice temperature and rheology}

The prognostic equation for internal ice temperatures $T\left(x, y, z^{\prime}, t\right)$ is

$$
\begin{aligned}
& \frac{\partial T}{\partial t}=-u \frac{\partial T}{\partial x}-v \frac{\partial T}{\partial y}-w^{\prime} \frac{\partial T}{\partial z^{\prime}} \\
& +\frac{1}{\rho_{i} c_{i} h^{2}} \frac{\partial}{\partial z^{\prime}}\left(k_{i} \frac{\partial T}{\partial z^{\prime}}\right)+\frac{Q_{i}}{\rho_{i} c_{i}}
\end{aligned}
$$

where $z^{\prime}=\left(h_{\mathrm{s}}-z\right) / h, k_{\mathrm{i}}=2.1 \times 365 \times 86400 \mathrm{~J} \mathrm{a}^{-1} \mathrm{~m}^{-1}$ $\mathrm{K}^{-1}$ is ice thermal conductivity, and $Q_{\mathrm{i}}$ is internal shear heating due to both SIA and SSA deformation. Only vertical heat diffusion is included; horizontal heat diffusion is assumed negligible on scaling grounds. Note that the vertical coordinate $z^{\prime}$ is dimensionless, and Eq. (15) has been transformed to this coordinate system (Huybrechts and Oerlemans, 1988; Ritz et al., 1997). The transformed vertical velocity $w^{\prime}=d z^{\prime} / d t$; numerical calculation of $w^{\prime}$ uses the technique in Ritz et al. (1997) (whose $w_{t}$ is our $w^{\prime} h$ ). Horizontal velocities $u, v$ are the sum of internal $(\sim$ SIA) shear and the basal velocity. The large-scale advective terms $\left(-u \partial T / \partial x-v \partial T / \partial y-w^{\prime} \partial T / \partial z^{\prime}\right)$ are calculated timeexplicitly, using upstream parabolic interpolation for $T$ (Farrow and Stevens, 1995).

The upper boundary condition is $T(x, y, 0, t)=$ surface ice temperature, deduced from surface air temperatures (Sect. 3 ). For grounded ice, the lower boundary condition at the ice base is that the vertical conductive flux $\left(k_{\mathrm{i}} / h\right) \partial T / \partial z^{\prime}$ at $z^{\prime}=1$ is equal to the vertical conductive flux at the top of the bedrock (see below) plus any basal shear heating $Q_{\mathrm{b}}=$ $\tilde{\tau}_{\mathrm{b}} . \tilde{u}_{\mathrm{b}} ;$ or, if $T(x, y, 1, t)$ would exceed the basal pressure melt point $T_{\mathrm{m}}$, then it is set equal to $T_{\mathrm{m}}$ and the imbalance in conductive fluxes plus $Q_{\mathrm{b}}$ is used to melt basal ice. For floating ice, the basal boundary condition is simply $T(x, y, 1, t)=T_{\mathrm{m}}$. (Oceanic melt rates under floating ice are parameterized separately in Sect. 2.8). 
Equation (15) is time-stepped with the vertical diffusive terms and boundary conditions treated time implicitly, which involves a standard tridiagonal solution versus $z^{\prime}$ for each ice column. To avoid numerical instability, very small ice thicknesses $(<1 \mathrm{~m})$ are treated as a thin film with zero heat capacity, but still with latent heat and melting if its temperature would otherwise exceed the pressure melt point.

Surface melting, refreezing and locally mobile liquid are calculated along with the surface mass balance (Sect. 3). Any locally mobile liquid (rain, snow melt and ice melt, minus refreezing) is assumed to immediately percolate downwards into the local vertical ice column, exchanging its latent heat with the sensible heat of the next lowest layer, i.e., if the layer is below freezing, then some (all) of the percolating liquid freezes, raising the layer temperature to (towards) the pressure melt point (and adding to the layer thickness). If the melt point is reached, the remaining water percolates down to the next layer, and so on. If any liquid reaches the base, it is added to any ice melt at the base itself, and is simply recorded as mass lost from the model (there is no basal hydrologic component).

The model includes vertical heat diffusion and storage in bedrock below the ice, heated from below by a specified geothermal heat flux. Nominally, and in all simulations shown below, its effect is minimized by using a very thin $(30 \mathrm{~m})$ single layer, so that the geothermal heat flux is essentially applied to the base of the ice. In other applications, it is typically $\sim 2 \mathrm{~km}$ thick with 6 unequally spaced layers (cf. Ritz et al., 1997). Physical and thermal properties of bedrock are given in Table 1.

In the ice dynamics (Sects. 2.2 and 2.3), the ice rheological coefficient $A$ and its dependence on temperature are specified as in Huybrechts (1998):

$$
\begin{aligned}
& A=E \times 5.47 \times 10^{10} e^{-13.9 \times 10^{4} /\left(8.314 T^{\prime}\right)} \\
& \text { if } T^{\prime} \geq 263.15^{\circ} \mathrm{K} \\
& A=E \times 1.14 \times 10^{-5} e^{-6.0 \times 10^{4} /\left(8.314 T^{\prime}\right)} \\
& \text { if } T^{\prime}<263.15^{\circ} \mathrm{K}
\end{aligned}
$$

where $T^{\prime}$ is the homologous ice temperature $T-T_{\mathrm{m}}$, where $T_{\mathrm{m}}=-.000866 z$ is the pressure melting point $\left({ }^{\circ} \mathrm{C}\right)$ and $z$ is depth (m) below ice surface. Units of $A$ are $\mathrm{a}^{-1} \mathrm{~Pa}^{-3}$ corresponding to $n=3$ in Eqs. (1) to (7). The enhancement factor $E$ is set to 1 for SIA flow in Eq. (1) (see PD12), and to 0.3 for SSA flow (Eqs. 2 and 8). The ratio of enhancement factors represents differences in fabric anisotropy between grounded and shelf ice (Ma et al., 2010); it is similar to but somewhat smaller than their suggested range of 5:1 to 10:1.

\subsection{Sub-ice-shelf oceanic melting}

The simulation of oceanic melting at the base of Antarctic ice shelves is challenging, involving incursions of Circumpolar Deep Water (CDW) or High Salinity Shelf Water (HSSW) and other mechanisms that differ from basin to basin (e.g., Nicholls et al., 2009; Walker et al, 2009; Jenkins et al., 2010; Pritchard et al., 2012). Coupling with ice sheet models will ultimately require high-resolution 3-D regional ocean modeling (e.g., Dinniman et al., 2011; Hellmer et al., 2012), especially for paleo and future scenarios. For now, we use simple parameterizations that attempt to provide (i) the basic modern spatial distribution, and (ii) paleoclimatic variations that yield results in accord with geologic data.

In PD09, the parameterization of modern oceanic melt rates was somewhat ad hoc, based on subtended arcs to open ocean. Our current parameterization described below follows Martin et al. (2011) for the PISM-PIK model. A new parameterization based on Olbers and Hellmer's (2010) more physical cavity-box model (Gladstone et al., 2012b; Winkelmann et al., 2012) is under development.

Similarly to Martin et al. (2011), the oceanic melt rate at the base of floating ice $\left(\mathrm{m} \mathrm{a}^{-1}\right)$, OMB in Eq. (14), is given by

$\mathrm{OMB}=\frac{K K_{T} \rho_{w} c_{w}}{\rho_{i} L_{f}}\left|T_{o}-T_{f}\right|\left(T_{o}-T_{f}\right)$

where $T_{\mathrm{o}}$ is the specified ocean water temperature, and $T_{\mathrm{f}}$ $=.0939-.057 \times 34.5-.000764 z\left({ }^{\circ} \mathrm{C}\right)$ is the ocean freezing point at ice-base depth $z(\mathrm{~m})$ (Beckmann and Goose, 2003; cf. Jenkins and Bombosch, 1995). The transfer factor $K_{T}=5 \times 10^{-7} \times 365 \times 86400=15.77 \mathrm{~m} \mathrm{a}^{-1} \mathrm{~K}^{-1}$ (as in Martin et al. at $T_{\mathrm{o}}-T_{\mathrm{f}}=1^{\circ} \mathrm{C}$ ), and $K$ is an additional $O(1)$ basin-dependent factor given below. Because the freezing point $T_{\mathrm{f}}$ decreases with depth, the dependence on $T_{\mathrm{o}}-T_{\mathrm{f}}$ means that melt rates tend to be higher at the grounding line as deduced from observations. Unlike Martin et al. (2011), the dependence on temperature difference $T_{\mathrm{O}}-T_{\mathrm{f}}$ is quadratic (Holland et al., 2008).

Here, the ocean temperature $T_{\mathrm{o}}$ is specified differently for various Antarctic sectors, based on observations but mainly aiming to produce realistic modern ice-shelf extents and grounding-line positions. The 4 sectors are delineated by crude latitude and longitude ranges, as follows (with latitudes in ${ }^{\circ} \mathrm{N}$, longitudes in ${ }^{\circ} \mathrm{E}$, temperatures in ${ }^{\circ} \mathrm{C}$, and depths in meters), and also shown in Fig. 4a.

\section{- Amundsen and Bellingshausen Seas,} and Western Peninsula:

[longitude, latitude $]=[-140$ to $-120,>-77]$ or $[-120$ to $-90,>-85]$ or $[-90$ to $-65,>-75]$.

$T_{\mathrm{o}}-T_{\mathrm{f}}$ depends on depth $z$, based loosely on profiles in the outer Pine Island Bay with an upper layer of colder fresher water (Jacobs et al., 2011), which may be important for the survival of smaller shelves with shallow grounding lines: $T_{\mathrm{o}}-T_{\mathrm{f}}=0.5$ for $z<170,3.5$ for $z>680$, joined linearly from 170 to $680 \mathrm{~m}$.

$K=8$ (large, representing relatively direct access of CDW to these coasts) 
- Weddell embayment:

[longitude, latitude $]=[-120$ to $-90,<-85]$ or $[-90$

to $-65,<-75]$ or $[-65$ to -10 , all].

$T_{\mathrm{O}}=-0.8$

$K=1$

\section{- East Antarctica:}

[longitude, latitude $]=[-10$ to 160 , all $]$.

$T_{\mathrm{o}}-T_{\mathrm{f}}$ and $K$ are as for the Amundsen/Bellinghausen/W. Peninsula sector, even though ocean profile data in Prydz Bay for instance do not indicate a distinct upper layer as clearly as for Pine Island Bay (Smith et al., 1984).

\section{- Ross embayment:}

[longitude, latitude $]=[160$ to 180 , all $]$ or $[-180$ to -140 , all $]$ or $[-140$ to $-120,<-77]$.

$$
\begin{aligned}
& T_{\mathrm{o}}=-1.5 \\
& K=1
\end{aligned}
$$

At this point, $T_{\mathrm{O}}$ and $K$ represent conditions under modern exposed shelves. For the West Antarctic sectors, ocean melt is further reduced based on subtended arc to open ocean $A_{a}$ (degrees), i.e., the angle formed by the set of all straight lines from the point in question that reach open ocean without hitting land (as in PD09).

$T_{\mathrm{o}}^{\prime}=T_{o} w_{a}+(-1.7)\left(1-w_{a}\right)$

$K^{\prime}=K w_{a}+1 \times\left(1-w_{a}\right)$

where

$w_{a}=\max \left[0, \min \left[1,\left(A_{a}-50\right) / 20\right]\right]$

This has the effect of reducing ocean melting for regions mostly surrounded by land. It is found to be necessary in long-term paleo runs (Sect. 5 below) to allow WAIS to regrow after a collapse of all marine ice. After a collapse, the surviving small terrestrial ice caps on Western Antarctic islands must first form thin ice shelves that grow over the interior seaway, coalesce, thicken and become buttressed so as to allow grounding lines to advance out from the islands. Equation (18) can be justified by arguing that interior seaways mosly surrounded by land were more protected from warm water intrusions than the modern coast and embayments. This hypothesis should be tested by regional ocean modeling of the environment following a major WAIS collapse. Equation (18) is not applied to East Antarctica for the ad hoc reason that ocean melting from Eq. (17) needs to penetrate into the Lambert Graben in order to produce reasonable modern grounding line and shelf extents there. A similar parameterization to Eq. (18) is also used to restrict calving (Sect. 2.10).
The above yields the distribution of modern ocean melt rates, shown in Fig. 4b. For paleoclimatic applications, longterm climate variations are parameterized much as in PD09, based on a single weighting parameter $w_{\mathrm{c}}$ set proportional to deep-sea core $\delta^{18} \mathrm{O}$, plus a slight influence of austral summer insolation:

$$
\begin{aligned}
& w_{\mathrm{c}}=\max \\
& {\left[0, \min \left[2,1+S / 85+1 \times \log \left(r \mathrm{CO}_{2}\right) / \log (2)\right.\right.} \\
& \left.\left.\quad+\max \left[0,0.1 \Delta Q_{80} / 3\right]\right]\right]
\end{aligned}
$$

where $S$ is eustatic sea level relative to modern (meters), set proportional to $\delta^{18} \mathrm{O}$ (Lisiecki and Raymo, 2005) with modern $\delta^{18} \mathrm{O}$ corresponding to $0 \mathrm{~m}$ and Last Glacial Maximum $\delta^{18} \mathrm{O}$ corresponding to $-125 \mathrm{~m} . \Delta Q_{80}$ is the change in January insolation at $80^{\circ} \mathrm{S}$ from modern $\left(\mathrm{W} \mathrm{m}^{-2}\right.$ ) (Laskar et al., 2004). $r \mathrm{CO}_{2}$ is atmospheric $\mathrm{CO}_{2}$ in units of preindustrial level (280 ppmv), used mainly for deeper time (pre-Pliocene) experiments. For fixed pre-industrial $\mathrm{CO}_{2}, w_{\mathrm{c}}$ varies between 0 for glacial maxima, 1 for modern-like climates, and 2 for warmest interglacials. $w_{\mathrm{c}}$ is converted to 3 weights for those 3 climates (each between 0 and 1 , summing to 1 ):

$w_{\text {lgm }}=\left(1-w_{\mathrm{c}}\right), w_{\text {mod }}=w_{\mathrm{c}}, w_{\text {hot }}=0$ for $0 \leq w_{\mathrm{c}} \leq 1$

$w_{\text {lgm }}=0, w_{\text {mod }}=\left(2-w_{\mathrm{c}}\right), w_{\text {hot }}=\left(w_{\mathrm{c}}-1\right)$ for $1<w_{\mathrm{c}} \leq 2$

which are used to alter the ocean temperature and basin factor from Eq. (18):

$T_{o}^{\prime \prime}=-1.7 w_{\operatorname{lg~m}}+T_{o}^{\prime} w_{\text {mod }}+5 w_{\text {hot }}$

$K^{\prime \prime}=K^{\prime} w_{\operatorname{lg~m}}+K^{\prime} w_{\text {mod }}+8 w_{\text {hot }}$

Finally, $T_{\mathrm{o}}^{\prime \prime}$ and $K^{\prime \prime}$ are modified for distal locations, to prevent ice shelves from expanding into the Southern oceans far from Antarctica. This is based on ocean bathymetry $\left(h_{\mathrm{w}}\right.$ $=$ sea level $-h_{\mathrm{b}}$ ), assuming much warmer waters at depths $>\sim 2000 \mathrm{~m}$, with an additional constraint based on the arcto-open-ocean angle $A_{a}$ to ensure this is not done for deep proximal troughs. The final $T_{\mathrm{o}}^{\prime \prime \prime}$ and $K^{\prime \prime \prime}$ are used in Eq. (17) in place of $T_{\mathrm{o}}$ and $K$.

$T_{o}^{\prime \prime \prime}=T_{o}^{\prime \prime}\left(1-w_{d} w_{e}\right)+\max \left[T_{o}^{\prime \prime}, T_{\mathrm{dist}}\right] w_{d} w_{e}$

$K^{\prime \prime \prime}=K^{\prime \prime}\left(1-w_{d} w_{e}\right)+10 w_{d} w_{e}$

where

$T_{\text {dist }}=-0.5 w_{\operatorname{lgm}}+5 w_{\text {mod }}+8 w_{\text {hot }}$

$w_{d}=\max \left[0, \min \left[1,\left(h_{\mathrm{w}}-1900\right) / 200\right]\right]$

$w_{e}=\max \left[0, \min \left[1,\left(A_{a}-150\right) / 20\right]\right]$ 


\subsection{Sub-grid ice shelf fraction}

In order for the model to represent vertical tidewater faces, and to avoid whole grid-cell jumps in the advance and retreat of ice shelves, floating ice is allowed to occupy a subgrid fraction of cell area, $f_{\mathrm{e}}$. This is only applied at ice shelf edges adjacent to open ocean; for interior shelf and all grounded points, $f_{\mathrm{e}}=1$. The motivation and method here closely follow Albrecht et al. (2011) for the PISM-PIK model.

For floating ice cells adjacent to open ocean, the sub-grid actual thickness (within the area $f_{\mathrm{e}}$ ) is estimated based on the thickness of adjacent, presumably upstream, ice (Albrecht et al., 2011). All adjacent points are examined, and the maximum of their ice thicknesses $(h)$ is taken, but only if they are grounded, or are floating and not themselves adjacent to open ocean. Furthermore, if grounded, the interpolated thickness at the grounding line is used.

Then this maximum thickness, $h_{\max }(\mathrm{m})$ say, is reduced to allow for typical downstream thinning into the cell in question:

$h_{e}=\max \left[h_{\max } \max \left(0.25, e^{\left(-h_{\max } / 100\right)}\right), 30, h\right]$

where the minimum of $30 \mathrm{~m}$ avoids very thin shelves, and $h_{\mathrm{e}}$ can also not be less than the current cell-mean thickness $h$. $h_{\mathrm{e}}$ is the estimated actual ice thickness within areal fraction $f_{\mathrm{e}}$ of the cell in question.

Finally, to implicitly conserve ice mass, the fractional area occupied by ice in this cell is reset to

$f_{\mathrm{e}}=h / h_{\mathrm{e}}$

where $h$ is the cell-mean thickness $h$ (ice volume divided by cell area). Note that the settings above are only done for floating ice cells adjacent to open ocean, otherwise $f_{\mathrm{e}}=1$ and $h_{\mathrm{e}}=h$. The variable $f_{\mathrm{e}}$ is used elsewhere in the model to scale quantities that truly depend on area of ice, i.e., surface mass balance and oceanic melting are both multiplied by $f_{\mathrm{e}}$ in the ice thickness evolution as in Eq. (14). Also, as mentioned in Sect. 2.2, no advective flow of ice is allowed out of a cell with $f_{\mathrm{e}}<1$.

\subsection{Calving at ice-shelf edge}

There has been considerable recent activity in modeling calving of tidewater glaciers and ice shelves, in part because the extent of floating ice can affect the amount of back stress (buttressing) at the grounding line, and hence the stability of grounded ice upstream (Scambos et al., 2004). Various mechanisms or triggers have been represented in models, including ice thickness over flotation, penetration of crevasses and surface water, and large-scale stress fields (reviewed by Benn et al., 2007; also for instance Alley et al., 2008; Nick et al., 2010; Levermann et al., 2012), but there is little consensus on the main mechanism or mechanisms.

The calving parameterization here is based on the largescale stress field, represented by the horizontal divergence of
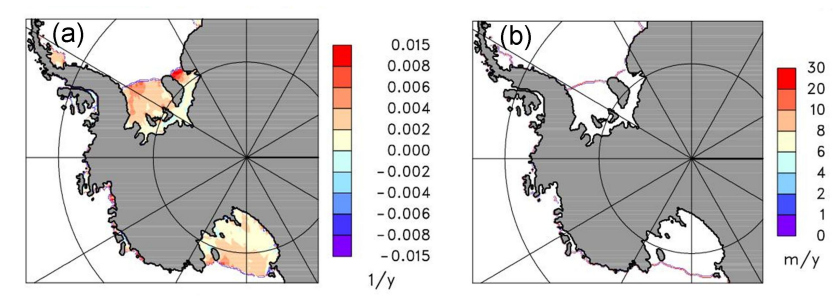

Fig. 5. (a) Divergence $\partial u / \partial x+\partial v / \partial y\left(\mathrm{a}^{-1}\right)$ of floating ice, in nested $10 \mathrm{~km}$ modern simulation with constrained grounding lines and shelf geometry (as in PD12). (b) Loss due to calving (CMB, $\mathrm{m} \mathrm{a}^{-1}$ ).

floating ice velocities. It shares the same motivation as earlier studies by Doake et al. (1998) and is similar to the parameterization in PISM-PIK (Martin et al., 2011; Winkelmann et al., 2011; Levermann et al., 2012), but without using principal strains, i.e., with no distinction between along-flow and across-flow strains, as in Amundson and Truffer (2010). Inclusion of fracture propagation (e.g., Hulbe et al., 2010; Albrecht and Levermann, 2012), multiple stable states (Levermann et al., 2012) and other calving mechanisms are deferred to future work.

First, the divergence of floating ice shelf points div is calculated as

$\operatorname{div}=\partial \bar{u} / \partial x+\partial \bar{v} / \partial y$

using $\bar{u}$ and $\bar{v}$ from the solution of the SSA Eqs. (2a, b) above. This is done only for floating grid points with full fractional $\operatorname{cover}\left(f_{\mathrm{e}}=1\right.$, Sect. 2.9), and propagated by nearest-neighbor value to those on the shelf edge with $f_{\mathrm{e}}<1$. Then, for points at the shelf edge adjacent to open ocean, the grid-mean calving loss CMB ( $\mathrm{m} \mathrm{a}^{-1}$, used in Eq. 14) is set as a weight between two values:

$\mathrm{CMB}=\left(1-w_{\mathrm{c}}\right) 30+w_{\mathrm{c}} 3 \times 10^{5} \max (\operatorname{div}, 0) h_{e} / d x$

where the weight $w_{\mathrm{c}}=\min \left(1, h_{\mathrm{e}} / 200\right)$. Here, $h_{\mathrm{e}}$ is the subgrid thickness of ice within fraction $f_{\mathrm{e}}$ (Sect. 2.9), and $d x$ is the grid cell size. All units are meters and years. For thin shelves $\left(h_{\mathrm{e}}<<200 \mathrm{~m}\right)$, calving is simply weighted towards a constant value of $30 \mathrm{~m} \mathrm{a}^{-1}$. For thicker shelves, it is weighted towards a value proportional to divergence $\operatorname{div}\left(\mathrm{a}^{-1}\right)$, but only for positive div.

The thickness $h_{\mathrm{e}}$ and grid size $d x$ enter in Eq. (26) because $3 \times 10^{5} \max (\mathrm{div}, 0)$ represents the calving rate (i.e., average horizontal speed of erosion of the shelf edge into the interior, $U_{\mathrm{c}}$ in Benn et al., 2007), but CMB here is the rate of volume of ice removed from the cell divided by cell area, so the expression is multiplied by $h_{\mathrm{e}} d x / d x^{2}$.

The magnitude of the $3 \times 10^{5}$ coefficient $(\mathrm{m})$ is reasonable on scaling grounds. For a steady-state edge position, the calving rate $\left(U_{\mathrm{c}}=3 \times 10^{5} \mathrm{div}\right)$ must balance the advective ice velocity just upstream of the edge $\left(U_{T}\right)$. For the large 
West Antarctic shelves, ice velocities change significantly upstream on scales of several $100 \mathrm{~s} \mathrm{~km}, L_{T}$ say, so the divergence at the edge is on the order of $U_{T}$ divided by $L_{T}$. In that case, the parameterized $U_{\mathrm{c}}=3 \times 10^{5} U_{T} / L_{T}$, which is the same order as $U_{T}$ as required for steady state.

CMB is further modified for seaways mostly surrounded by land, represented by the angle subtended to open ocean, $A_{a}$. This quantity is also used to modify oceanic melt (Sect. 2.8, Eq. 18). As discussed in that section, these modifications are needed to allow regrowth of thin shelves in central West Antarctic seaways following a major WAIS collapse (in contrast to the vigorous calving at the edges of the thicker Ross and Weddell shelves today). It can be motivated by considering the effects of icebergs clogging in the restricted seaways, possibly creating a melange that inhibits further calving, but this needs to be explored by future modeling (cf. Vaughan et al., 2011). The calving loss rate CMB is reduced by

$\mathrm{CMB}^{\prime}=\mathrm{CMB} \max \left[0, \min \left[1,\left(A_{a}-70\right) / 20\right]\right]$

The divergence div and calving loss given by Eqs. (26) and (27) are shown in Fig. 5 for a modern nested West Antarctic simulation. In practice, ice-edge thicknesses are often considerably less than $200 \mathrm{~m}$, so the weight $w_{\mathrm{c}}$ in Eq. (26) is $\sim 0$, and CMB is close to the constant $30 \mathrm{~m} \mathrm{a}^{-1}$ in many regions, as seen in Fig. 5. This will be improved in a new calving parameterization under development (see below).

For past climates, calving is reduced for cooler environments, similarly to ocean melt in Sect. 2.8. This is somewhat ad hoc, because the dependence of divergence on calving does not directly depend on temperature, as some of the other mechanisms mentioned above. But we find that calving must be reduced in order to allow grounding lines to expand as observed during glacial maximum periods.

$\mathrm{CMB}^{\prime \prime}=\mathrm{CMB}^{\prime}\left(0 \times w_{\lg m}+1 \times w_{\text {mod }}+1 \times w_{\text {hot }}\right)$

where $w_{\text {lgm }}, w_{\text {mod }}$ and $w_{\text {hot }}$ are the 3 climate weights corresponding to glacial maxima, modern-like and warm interglacial conditions (as in Sect. 2.8, Eq. 20). We are currently developing a new calving parameterization with surface melt dependence, which may avoid the questionable dependencies in Eqs. (27) and (28).

\subsection{Oceanic melt at vertical faces}

The parameterization of sub-grid areal fraction in Sect. 2.9 allows tall vertical ice faces to be in contact with the ocean, including tidewater fronts extending one grid cell from deep grounding lines. Observations at Greenland calving faces show that oceanic melting of the submerged ice front can be up to a few meters per day (Rignot et al., 2010). A parameterization of the actual circulation and melt rates at a vertical face (Motyka et al., 2003) is not yet in the model. As a placeholder for now, we calculate the area of each vertical face in contact with the ocean, and simply apply oceanic sub-ice melt rates from Sect. 2.8 to that area. For any ice cell adjacent to and in contact with open ocean, the vertical extent of submerged ice is

$\Delta z=\frac{\rho_{i}}{\rho_{w}} h_{e}$ for floating ice

$\Delta z=S-h_{\mathrm{b}}$ for grounded ice

where $S$ is sea level and $h_{\mathrm{b}}$ is bed elevation. For each of the (up to 4) neighboring cells with no ice and open ocean, $\Delta z$ is multiplied by the length of the interface ( $d x$ for Cartesian grids) and by that cell's oceanic sub-ice melt (OMB from Sect. 2.8). These are summed, and divided by the cell area $\left(d x^{2}\right)$ to yield the cell-mean loss of ice due to face melting FMB used in Eq. (14).

\subsection{Bedrock deformation}

As in Huybrechts and de Wolde (1999) and Ritz et al. (1997, 2001), the response of the bedrock to the changing ice and ocean load is a combination of time-lagged asthenospheric relaxation towards isostatic equilibrium, and modification of the applied load by the elastic lithosphere. The treatment here exactly follows Huybrechts and de Wolde (1999). The downward deflection $w_{\mathrm{b}}$ of the fully relaxed response (as if the asthenosphere had no lag) is given by

$D \nabla^{4} w_{\mathrm{b}}+\rho_{\mathrm{b}} g w_{\mathrm{b}}=q$

where $D=10^{25} \mathrm{~N} \mathrm{~m}$ is the flexural rigidity of the lithosphere, $\rho_{\mathrm{b}}$ is the bedrock (asthenospheric) density and $g$ is gravitational acceleration. A lower value of $D\left(\sim 10^{23}\right.$ to $\left.10^{24} \mathrm{~N} \mathrm{~m}\right)$ can optionally be used for West Antarctica (cf. Stern and ten Brink, 1989). The applied load $q$ is

$q=\rho_{i} g h+\rho_{w} g h_{w}-\rho_{i} g h_{i}^{\mathrm{eq}}-\rho_{w} g h_{w}^{\mathrm{eq}}$

where $h$ is ice thickness, $h_{\mathrm{w}}$ is ocean column thickness, and $h^{\mathrm{eq}}$ and $h_{\mathrm{w}}^{\mathrm{eq}}$ are their values in the equilibrium state (see below).

Equation (30) is solved by a Green's function method. The response to a point load $P$ ( $q$ times area) versus radial distance $r$ is

$w_{p}(r)=\frac{P L^{2}}{2 \pi D} \operatorname{kei}(r / L)$

where kei is a Kelvin function of zeroth order (Brotchie and Silvester, 1969), and $L=\left(D / \rho_{\mathrm{b}} g\right)^{1 / 4}=132 \mathrm{~km}$ is a flexural length scale. $w_{\mathrm{p}}$ has significant amplitude within several $L$ lengths of the point load. The $w_{\mathrm{p}}$ are summed over the individual point loads of all grid cells (with $P=q \times$ cell area) to give $w_{\mathrm{b}}(x, y)$, the deflection of the bedrock surface from equilibrium that would occur if the asthenosphere relaxed instantaneously. This is assumed to be proportional to the unbalanced pressure at the top of the asthenosphere due to the 
load alone (Brotchie and Silvester, 1969). The actual bedrock rate of change is given by

$$
\frac{\partial h_{\mathrm{b}}}{\partial t}=-\frac{1}{\tau}\left(h_{\mathrm{b}}-h_{\mathrm{b}}^{\mathrm{eq}}+w_{\mathrm{b}}\right)
$$

where $h_{\mathrm{b}}$ is current bedrock elevation, $h_{\mathrm{b}}^{\mathrm{eq}}$ is its equilibrium value, and $\tau$ is $3000 \mathrm{yr}$.

The equilibrium state ( $h^{\mathrm{eq}}$ and $h_{\mathrm{w}}^{\mathrm{eq}}$ in Eq. $31, h_{\mathrm{b}}^{\mathrm{eq}}$ in Eq. 33 ) is taken to be the modern observed, assuming that any glacial isostatic adjustments still to occur from the last deglaciation can be neglected (cf. PD12 Appendix B). Equivalently, at the start of a run, the bedrock model alone can be spun up for several 10000 s years with all ice removed, and the resulting ice-free equilibrated state can be used to define $h_{\mathrm{b}}^{\mathrm{eq}}, h_{\mathrm{w}}^{\mathrm{eq}}$ (and $\left.h^{\mathrm{eq}}=0\right)$

\subsection{Time steps, adaptive time stepping}

The main ice-dynamical time step $\Delta t_{\mathrm{i}}$ (for Eq. 14) is selected for most experiments depending on model resolution, for instance $\sim 0.1$ to $0.5 \mathrm{yr}$ for 5 to $10 \mathrm{~km}, \sim 0.5$ to $1 \mathrm{yr}$ for $20 \mathrm{~km}$, and 2 to $5 \mathrm{yr}$ for $40 \mathrm{~km}$. There is an option for adaptive time stepping that circumvents numerical instabilities, as follows. A restart file is saved at regular time points during a run (spaced $\sim 1000 \mathrm{yr}$ apart typically). If a numerical exception $(\mathrm{NaN})$ occurs or if physically unreasonable values of ice thickness, temperature or velocity are detected, the simulation reverts to the previous time point using the last restart file, and tries again to run through the next $1000 \mathrm{yr}$ with the time step halved. If an anomaly still occurs during the next $1000 \mathrm{yr}$, the process is repeated, and is attempted up to 4 times (i.e., with time steps as small as $2^{-4} \times$ the nominal value) before aborting. If an attempt makes it through the next $1000 \mathrm{yr}$ successfully, the time step is reset to the nominal value and the run continues on.

For the NetCDF history files, no special action is needed if this adaptive time-looping occurs, because the model snapshots have a unique time index and overwrite any previous snapshot with the same time value. For sequential (ascii) files that contain output at regular intervals, marker records are written that allow a postprocessing program to recognize any time-looping and delete repeated sections as needed. The adaptive-time-stepping capability can be convenient near the start of experiments that are initialized to a state far from equilibrium with the boundary conditions (e.g., modern ice sheet and other geologic time periods). In those cases, blowups and adaptive time looping tend to occur in the first few hundred years, after which the model becomes adjusted to the boundary conditions and the run continues normally.

Other components of the model are time-stepped or reset at greater intervals. The various intervals are as follows:

- Ice thickness and dynamics Eq. (14): $\Delta t_{\mathrm{i}}$, depends on resolution as above.
- Ice and bed temperatures Eq. (15): $50 \mathrm{yr}$, or $\Delta t_{\mathrm{i}}$ for $10 \mathrm{~km}$ resolution or less.

- Bedrock deformation Eq. (33): $50 \mathrm{yr}$.

- Resetting oceanic melt and calving parameterizations (Sect. 2.8 and 2.9): $\Delta t_{\mathrm{i}}$.

- Resetting parameterized climate (Sect. 3): $50 \mathrm{yr}$.

- Resetting climate from global or regional climate models (Sect. 3): $1000 \mathrm{yr}$.

- Recalculating mass balance on ice surface (Sect. 3): 50 to $100 \mathrm{yr}$. At intervening times, recalculation is done for any ice points whose elevation changes by more than $50 \mathrm{~m}$.

\section{Input datasets and climate forcing}

Modern Antarctic input fields are obtained mainly from the ALBMAP v1 dataset at $5 \mathrm{~km}$ resolution (Le Brocq et al., 2010). The fields used to determine the equilibrium ice and bedrock state discussed in Sect. 2.12, with ALBMAP names in parentheses, are ice surface elevation (usrf), bedrock topography (lsrf, topg), and ice thickness (thk).

Various geothermal heat flux maps can be used in the model (Shapiro and Ritzwoller, 2004 (bheatflx_shapiro); Fox Maule et al., 2005 (bheatflx_fox); Pollard et al., 2005), but these differ considerably from each other on regional scales with noticeable effects on modern results (see next section). Rather than choose one or the other, in the nominal model we specify a simple two-value pattern, with $54.6 \mathrm{~mW} \mathrm{~m}^{-2}$ under EAIS and $70 \mathrm{~mW} \mathrm{~m}^{-2}$ under WAIS.

For runs with parameterized climate, observed annual accumulation rate $P$ (van de Berg et al., 2006 (accr)) and surface air temperature $T_{\mathrm{a}}$ (Comiso, 2000 (temp)) are used to calculate modern surface mass budgets, as follows:

1. First, $T_{\mathrm{a}}$ and $P$ are horizontally interpolated to the ice model grid, and vertical lapse rate corrections are applied:

$T_{\mathrm{a}}^{\prime}=T_{a}-\gamma\left(h_{s}-h_{s}^{\mathrm{obs}}\right)$

$P^{\prime}=P \times 2^{\left(T_{a}^{\prime}-T_{a}\right)} / \Delta T$

where $\gamma=.0080^{\circ} \mathrm{C} \mathrm{m}^{-1}, \Delta T$ is $10^{\circ} \mathrm{C}\left(15^{\circ} \mathrm{C}\right.$ in some runs), $h_{\mathrm{s}}$ is the model surface elevation and $h_{\mathrm{s}}^{\mathrm{obs}}$ is the modern observed elevation interpolated to the ice grid (similarly to Huybrechts, 1998; Ritz et al., 2001).

2. A sinusoidal seasonal cycle is added to $T_{\mathrm{a}}^{\prime}$, giving monthly air temperatures with peak-to-peak amplitude $20^{\circ} \mathrm{C}$ at sea level, increasing linearly with elevation to $30^{\circ} \mathrm{C}$ at $3000 \mathrm{~m}$, and $30^{\circ} \mathrm{C}$ above (based roughly on GCM climates in the GENESIS v3 model). 


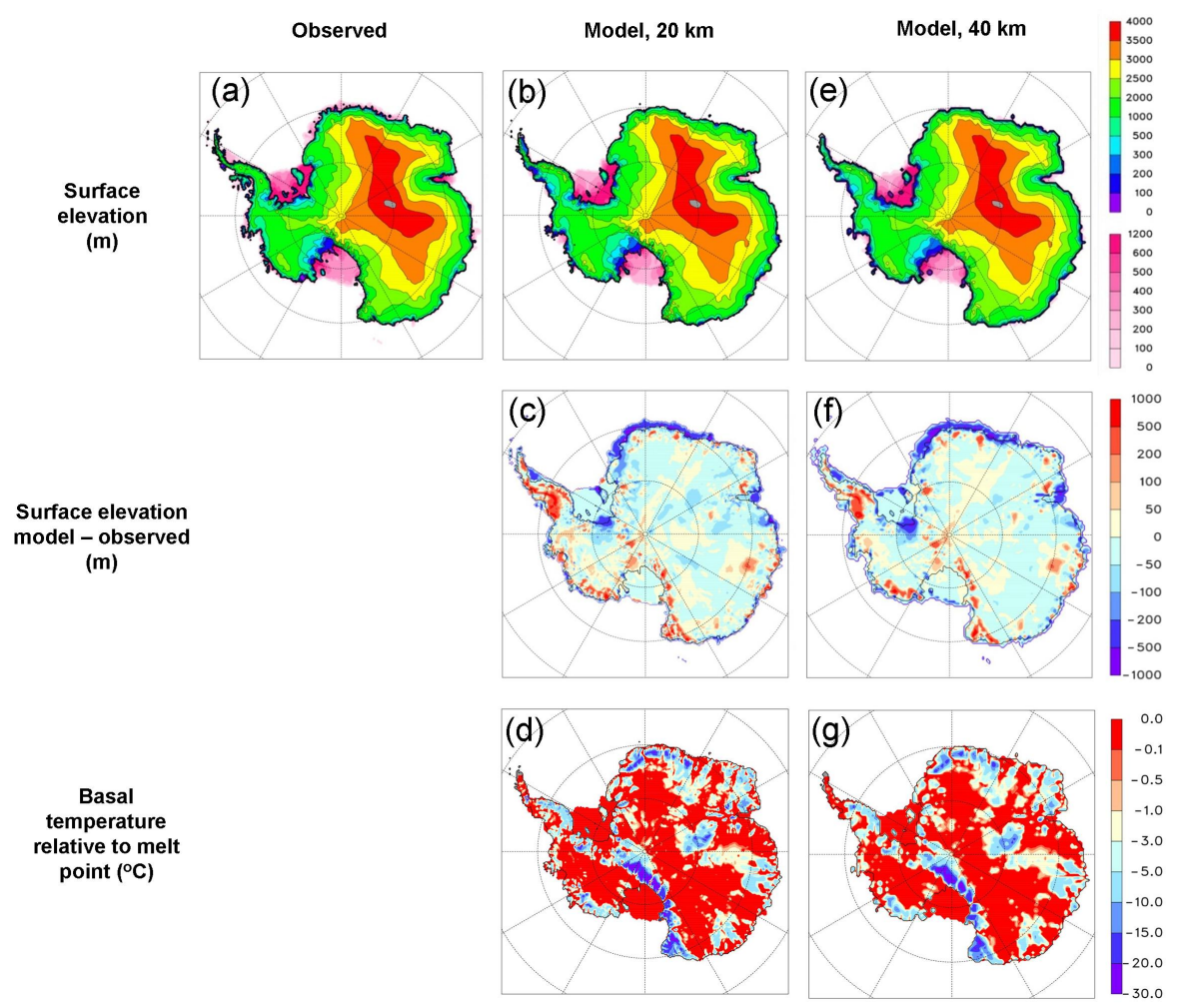

Fig. 6. (a) Left column (a): Modern observed (Le Brocq et al., 2010, averaged to $20 \mathrm{~km}$ grid). Middle column (b-d): Model, using basal sliding coefficient distribution from inverse method described in PD12, $20 \mathrm{~km}$ grid. Right column (e-g): Model, $40 \mathrm{~km}$ grid. Top row: Grounded ice surface elevations (upper scale) and floating ice thicknesses (lower scale), meters. Middle row: Difference in surface elevations, model minus observed, meters. Bottom row: Model basal homologous temperature (relative to pressure melting point), ${ }^{\circ} \mathrm{C}$.

3. A basic positive degree -day (PDD) scheme is applied to the monthly cycle, with coefficient $.005 \mathrm{~m}$ of melt per degree day. Monthly precipitation $P^{\prime}$ is either rain or snow depending on whether monthly air temperature is above or below $0^{\circ} \mathrm{C}$. Any melt or rain immediately becomes mobile and percolates into the ice sheet (Sect. 2.7). For modern runs, there is very little surface melt or rain on Antarctic ice. For paleo and future runs with significant melt and rain, a more detailed PDD scheme is available with seasonal refreezing, snow with liquid storage, distinct snow vs. ice PDD coefficients, and allowance for diurnal and synoptic variability (cf. Marshall et al., 2004). In future work we plan to include insolation explicitly (van de Berg et al., 2011).

4. The surface ice temperature, needed as a boundary condition in Sect. 2.7, is assumed to be the annual mean of $\min \left[\right.$ monthly air temperature, $\left.0^{\circ} \mathrm{C}\right]$.

For paleoclimate runs with parameterized climate, the modern surface $T_{\mathrm{a}}^{\prime}$ and $P^{\prime}$ are modified, very much as in PD09:

A. A spatially uniform shift $\Delta T_{a}$ is applied to air temperatures, mainly determined by deep-sea core $\delta^{18} \mathrm{O}$ and
$\mathrm{CO}_{2}$, with a minor effect of austral summer insolation (similarly to past ocean melt variations in Sect. 2.8, Eq. 19):

$\Delta T_{a}=10 \mathrm{~S} / 125+10 \log \left(\mathrm{rCO}_{2}\right) / \log (2)+0.1 \Delta Q_{80}$

where $S$ (meters) is eustatic sea level relative to modern, proportional to $\delta^{18} \mathrm{O}$ (as for Eq. 19). $r \mathrm{CO}_{2}$ is atmospheric $\mathrm{CO}_{2}$ in units of preindustrial level (280 ppmv), assumed to produce a $10^{\circ} \mathrm{C}$ warming in the Antarctic region for each $\mathrm{CO}_{2}$ doubling. $\Delta Q_{80}\left(\mathrm{~W} \mathrm{~m}^{-2}\right)$ is the change in January insolation from modern at $80^{\circ} \mathrm{S} . \Delta T_{a}$ is applied on the right-hand side of Eq. (34a) and so also affects precipitation $P^{\prime}$ in Eq. (34b).

B. The peak-to-peak amplitude of the sinusoidal seasonal temperature cycle (nominally 20 to $30^{\circ} \mathrm{C}$, step 2 above) is changed by $0.1 \Delta S Q_{80}$, where $\Delta S Q_{80}\left(\mathrm{~W} \mathrm{~m}^{-2}\right)$ is the change in January minus July insolation from modern at $80^{\circ} \mathrm{S}$.

Instead of parameterizing climate, the model can be driven by a global or regional climate model (GCM or RCM). The climate model provides monthly air temperature and precipitation to the interpolation and PDD schemes in steps 1 and 3 

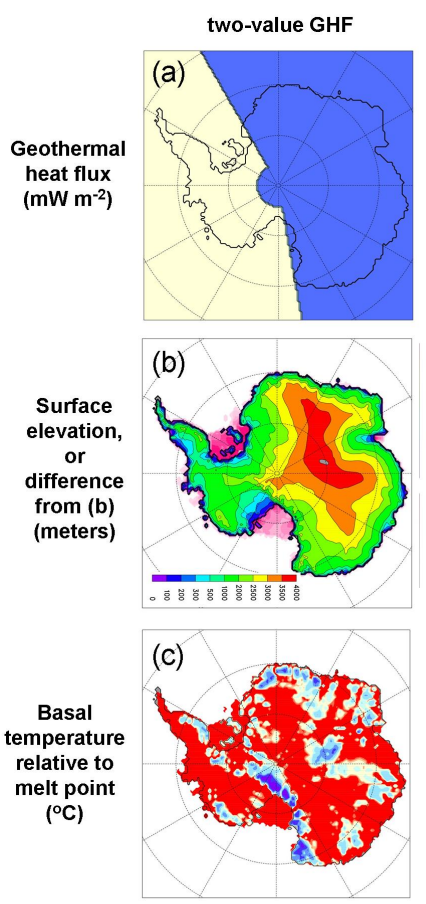
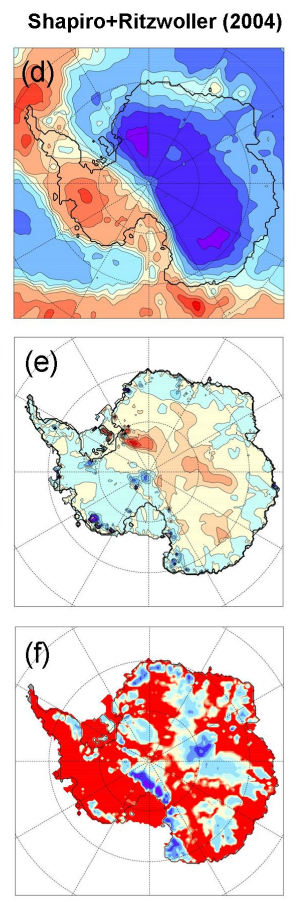
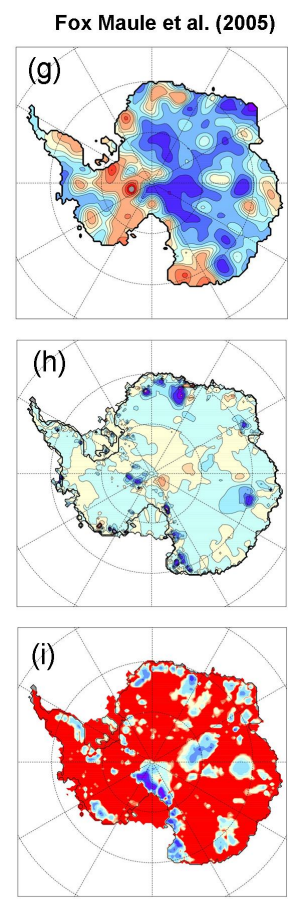
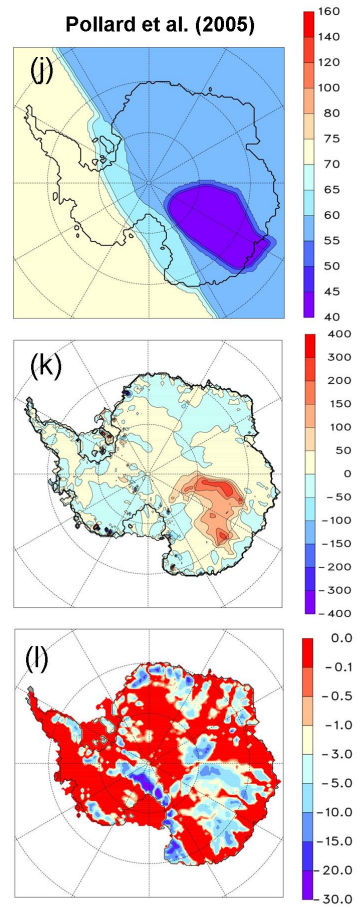

Fig. 7. Modern model results with various prescribed geothermal heat flux (GHF) distributions, $40 \mathrm{~km}$ resolution, using basal sliding coefficient distribution from inverse method described in PD12. Left column (a-c): with simple 2-valued GHF, default for this paper. Second column (d-f): with Shapiro and Ritzwoller (2004) GHF. Third column (g-i): with Fox Maule et al. (2005) GHF. Right column (j-l): with Pollard et al. (2005) GHF. Top row: GHF distributions, $\mathrm{mW} \mathrm{m}^{-2}$. Middle row: (b) Grounded ice surface elevations (upper scale) and floating ice thicknesses (lower scale), meters. (e, h, k): Difference from (b), meters. Bottom row: Basal homologous temperature (relative to pressure melting point), ${ }^{\circ} \mathrm{C}$.

above (e.g., DeConto and Pollard, 2003; Koenig et al., 2011; DeConto et al., 2011), or provides its own annual surface mass budgets calculated with full climate-model physics directly to the ice model.

\section{Modern results}

In this section, some basic model results for present-day Antarctica are compared with observations. These simulations have been run to equilibrium with the modern climate, so the comparison ignores any remaining glacial isostatic adjustments in the real world, which are relatively small compared to modern biases (PD12). As discussed in PD12, further work is planned with transient runs through the last deglaciation and extensive comparisons with paleo data (following Briggs et al., 2011; Whitehouse et al., 2012).

Figure 6 compares ice surface elevations $h_{\mathrm{s}}$ with observed, using the model with parameterized modern climate (Sect. 3) and inverse-derived basal sliding coefficients $C(x, y)$ (Sect. 2.4; PD12). Due mainly to the inverse-derived $C(x, y)$, model elevations are within a few 10 s meters of observed in most regions. Over the Transantarctics and some other mountain ranges, there are small patches with eleva- tions a few hundred meters too high. As discussed in PD12, these are thought to be due to insufficient sliding through deep troughs cutting through the mountains, only partially compensated by the sub-grid topographic parameterization in Eq. (12); however, further work is needed to test that hypothesis.

Much the same level of accuracy in $h_{\mathrm{s}}$ is maintained at different resolutions $(20 \mathrm{~km}$ and $40 \mathrm{~km}$ in Fig. $6 ; 10 \mathrm{~km}$ nested in PD12), which is somewhat surprising for regions such as the Siple Coast with ice streams that are scarcely resolved at $40 \mathrm{~km}$. Apparently the proto-streaming at 20 and $40 \mathrm{~km}$ does capture basic features such as interleaved unfrozen vs. frozen beds (Fig. $6 \mathrm{~d}, \mathrm{~g}$ ), and provides the correct overall flux to the grounding line. (At $10 \mathrm{~km}$ resolution, individual Siple Coast ice streams are simulated quite realistically, including century time-scale rerouting and stagnating; PD09 Supp. Inf.).

The model grounding line positions, ice shelf thicknesses and extents are the combined result of the model's SSA and SIA dynamics, grounding line flux prescription, and sub-ice oceanic melt, calving and sub-grid pinning parameterizations described above. They are not completely independent of model resolution (Fig. 6), but the effects of resolution are minor and considerably smaller than other model uncertainties. The major Ross and Filchner-Ronne shelves and grounding 

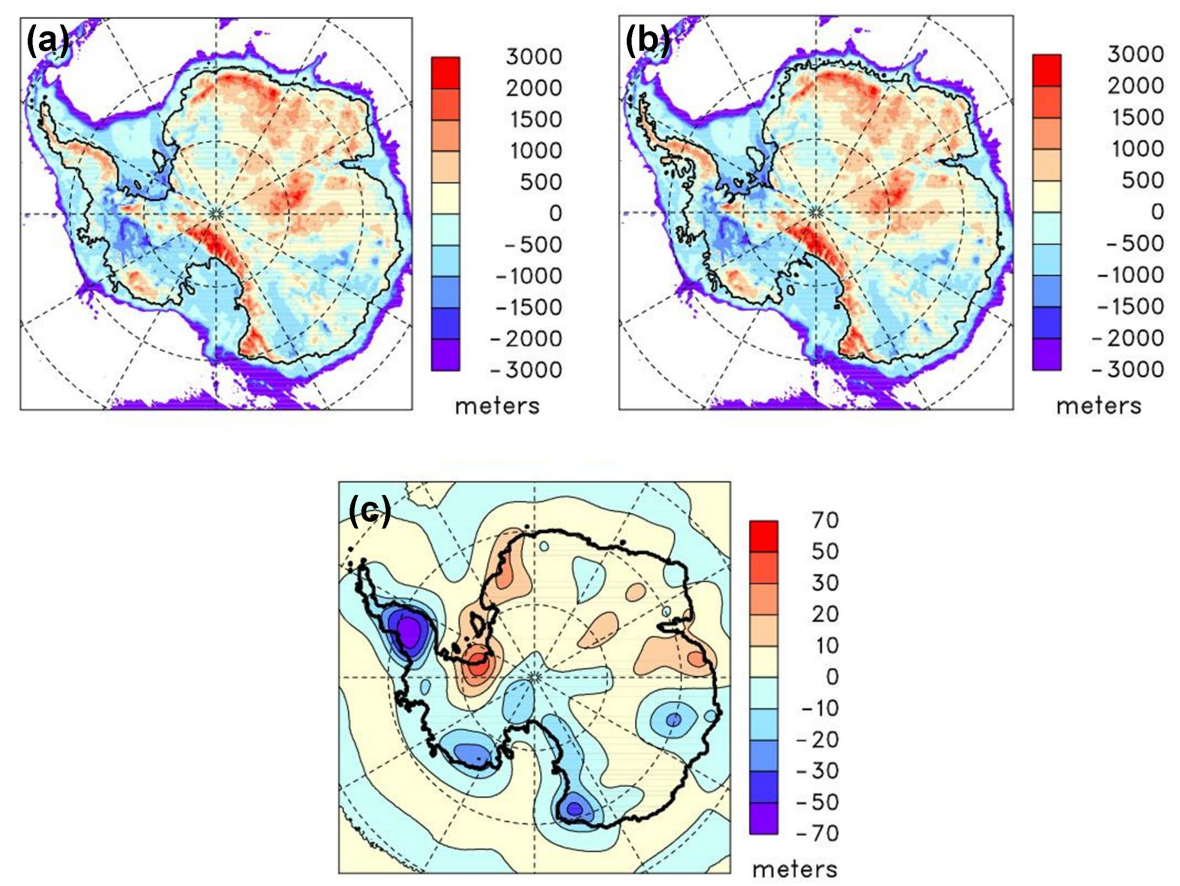

Fig. 8. (a) Bed elevations, meters, in modern simulation at $20 \mathrm{~km}$ resolution. (b) Observed modern bed elevations, meters (Le Brocq et al., 2010). (c) Difference, model minus observed.

lines are reasonably realistic, except that the Ronne grounding line has retreated about $200 \mathrm{~km}$ too far south (roughly between the Ellsworth Mountains and the Foundation Ice Stream), causing a pronounced low patch in Fig. 6c and f. Other smaller-scale grounding-line errors are seen in Pine Island Bay, Lambert Graben, and especially on the western Peninsula where George VI Sound (between Alexander Island and the mainland) is overridden with thick grounded ice in the model. The latter errors may require higher-resolution modeling and/or coupling with ocean models to correct entirely, but apart from George VI Sound, the errors are not huge and basic regional features are captured.

Figure 7 examines the model sensitivity to the prescribed geothermal heat flux (GHF) map. As noted above, GHF datasets differ significantly even at large scales (Fig. 7, top row). In PD12 we found that these differences can be accommodated by small adjustments in the inverse-derived distribution of basal sliding coefficients $C(x, y)$ (see Sect. 2.4). Here, we show the sensitivity of the model with fixed $C(x, y)$ used in this paper. As shown in Fig. 7, the various GHF maps cause regional and small-scale differences in surface ice elevation of $\sim 100$ to $200 \mathrm{~m}$, and significant changes in basal freezing vs. melting patterns. Analogous results are described in Pattyn et al. (2010) for Antarctica, and Rogozhina et al. (2012) for Greenland.

Modern bedrock elevations are also quite close to observed over most regions, showing that the bedrock model in Sect. 2.12 is reasonably realistic (Fig. 8). The largest dif- ferences are caused by two main grounding-line errors mentioned above, on the Ronne coast and George VI Sound. However, as discussed in PD12 (Appendices D, E), some of the general agreement may be fortuitous because the model has not taken transient residuals from the last deglaciation into account.

The recent all-Antarctic dataset of surface velocities (Rignot et al., 2011) provides the opportunity to comprehensively test the model velocity field, as shown in Fig. 9 where the dataset (900 $\mathrm{m}$ spacing) has been regridded by simple areaaveraging to the model's $20 \mathrm{~km}$ grid. Quantitative comparison is hindered by the fine scale and sharp gradients of many features in the dataset such as numerous outlet glaciers around the coast, many of which are barely resolved by the model and may be slightly displaced to one side or the other. Model speeds in the flanks around most coastlines are generally too fast, both in outlet glaciers and in the slower flow between them. The model's marginal ice thicknesses are generally close to observed (Fig. 6), so the discrepancy might be caused by too much snowfall near the coasts, or too much internal deformation compared to sliding. The biggest single velocity error in Fig. 9 is due to the Kamb Ice Stream (Ice Stream C) on the Siple Coast, which stagnated about 150 yr ago (Hulbe and Fahnestock, 2007), but in the model is flowing at velocities comparable to the other active Ross ice streams. This type of fluctuation could be stochastic in nature (Payne, 1999; PD09 Supp. Inf.). 

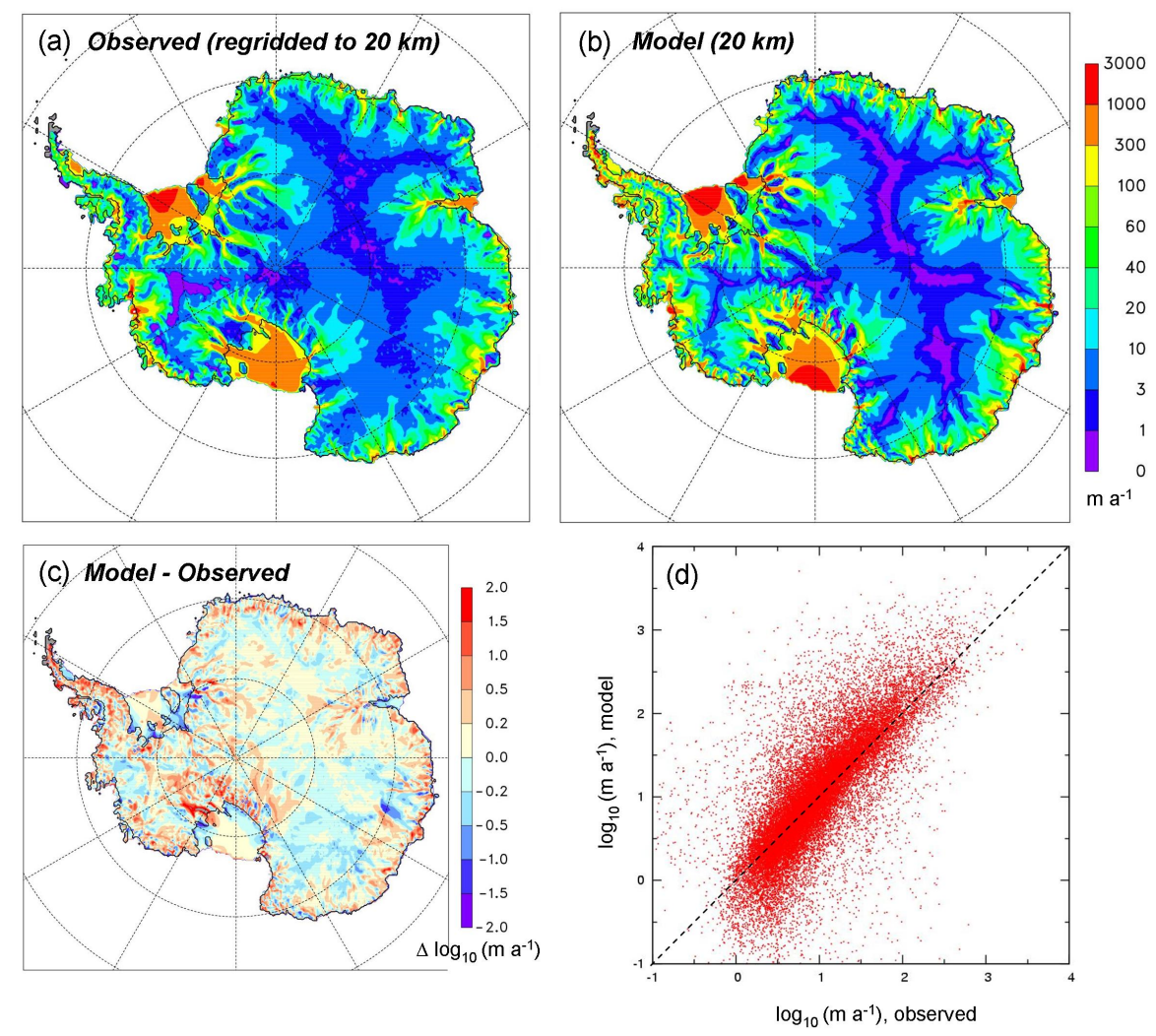

Fig. 9. (a) Observed surface ice velocity (Rignot et al., 2011), averaged here to $20 \mathrm{~km}$ model cells, $\mathrm{m} \mathrm{a}^{-1}$. (b) Model surface ice velocity, $\mathrm{m}$ $\mathrm{a}^{-1}$, in modern simulation at $20 \mathrm{~km}$ resolution. (c) Model minus observed $\log _{10}$ (velocity, $\mathrm{m} \mathrm{a}{ }^{-1}$ ), i.e., $\log _{10}\left(v_{\text {model }} / v_{\text {observed }}\right.$ ). Very slow velocities are ignored; i.e., if $v_{\text {model }}$ or $v_{\text {observed }}$ is less than $2 \mathrm{~m} \mathrm{a}^{-1}$, it is reset to $2 \mathrm{~m} \mathrm{a}^{-1}$ for this plot. (d) Scatter plot of observed vs. model velocities $\left(\log _{10}\left(\mathrm{~m} \mathrm{a}^{-1}\right)\right)$ for each $20-\mathrm{km}$ grid cell with grounded ice. The same figure appears in PD12.

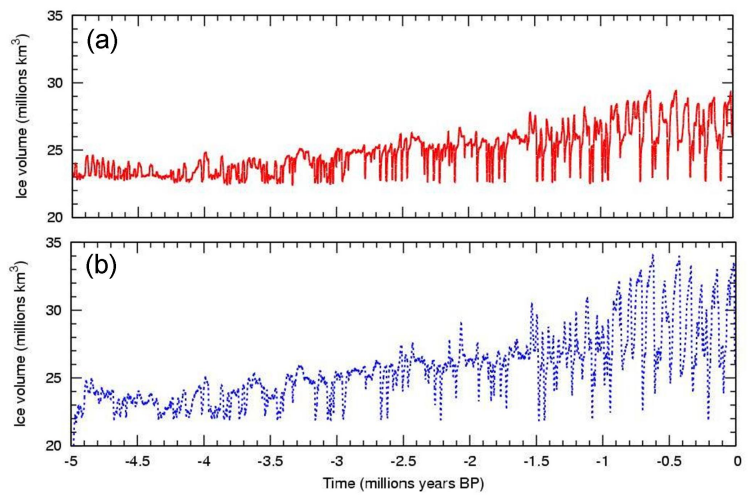

Fig. 10. Time series of total Antarctic ice volume $\left(10^{6} \mathrm{~km}^{3}\right)$ over the last 5 million years, in simulations with parameterized climatic and oceanic forcing dependent mainly on deep-sea core $\delta^{18} \mathrm{O}$, and slightly on austral summer insolation, with $40 \mathrm{~km}$ model resolution. (a) Current model, with inverse-derived basal sliding coefficients $C(x, y)$, and value on continental shelves $=10^{-5} \mathrm{~m} \mathrm{a}^{-1} \mathrm{~Pa}^{-2}$. (b) Earlier model version as in PD09 (their Fig. 3a) with simple twovalued $C(x, y)$ and continental-shelf value $=10^{-6} \mathrm{~m} \mathrm{a}^{-1} \mathrm{~Pa}^{-2}$.
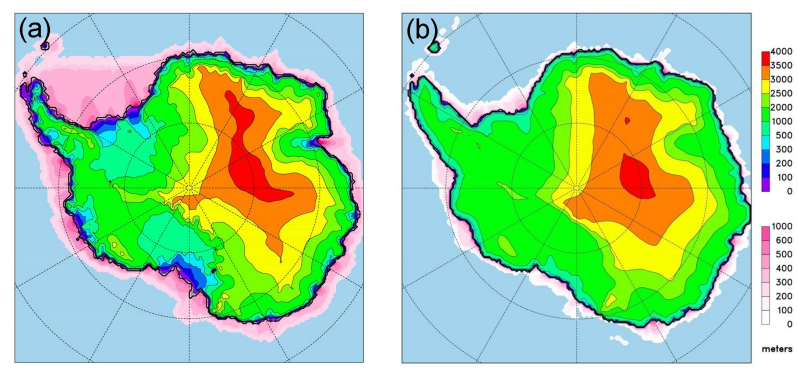

Fig. 11. Grounded ice surface elevations (upper scale, meters) and floating ice thicknesses (lower scale, meters), at $15 \mathrm{kyrs}$ $\mathrm{BP}$ in simulations of the last 5 million years. (a) Current model with inverse-derived basal sliding coefficients $C(x, y)$, and value on continental shelves $=10^{-5} \mathrm{ma}^{-1} \mathrm{~Pa}^{-2}$ (as Fig. 10a). (b) As in PD09, with simple two-valued $C(x, y)$ and continental-shelf value $=10^{-6} \mathrm{~m} \mathrm{a}^{-1} \mathrm{~Pa}^{-2}$ (as Fig. 10b). 


\section{Past $5 \mathrm{Myr}$ results, and last deglaciation issues}

In previous Antarctic applications, the model simulated glacial-interglacial variations in the Pliocene and Pleistocene that are in basic accord with observations (PD09). This includes reasonable first-order agreement with grounding-line retreat during the last deglaciation (last $\sim 20 \mathrm{kyrs}$ ) (PD09 Supp. Inf.), and with surface elevation histories deduced from field data in the Ohio Range (Ackert et al., 2011; Mukhopadhyay et al., 2012).

The applications in PD09 and Ackert et al. (2011) used an earlier model version with a simple two-value specification of basal sliding coefficients $\left(10^{-10}\right.$ and $10^{-6} \mathrm{~m} \mathrm{a}^{-1} \mathrm{~Pa}^{-2}$, Sect. 2.4, Fig. 3a). We repeated the simulations over the last 5 Myrs in PD09 with the current model including the new inverse-derived $C(x, y)$ distribution, and with $C(x, y)=10^{-5} \mathrm{~m} \mathrm{a}^{-1} \mathrm{~Pa}^{-2}$ (maximum value, slippery sediment) specified for all modern ocean beds. As shown in Fig. 10, the results have the same basic features, with predominantly collapsed WAIS in the warm Pliocene, transitioning to larger glacial-interglacial cycles in the Pleistocene, and rarer WAIS collapses in a few Pleistocene interglacials.

However, the maximum glacial ice volumes are less in the current model, $\sim 29 \times 10^{6} \mathrm{~km}^{3}$ compared to $\sim 33 \times 10^{6} \mathrm{~km}^{3}$ in PD09. This is probably due to greater extents of slipperier beds in the new version (PD09 Supp. Inf. Fig. S7A showed much the same effect). Consequently, the equivalent eustatic sea level rise predicted between the Last Glacial Maximum (LGM) and today is only $+1.6 \mathrm{~m}$ in the new version (3.5 from WAIS, -1.9 from EAIS due to increasing snowfall), compared to $+12 \mathrm{~m}$ in PD09. These differences in LGM volume are mainly due to thinner ice on the continental shelves and parts of West Antarctica in the current model (Fig. 11). The different ice thicknesses around the margins affect the timing of grounding-line retreat in the major embayments, and simulated relative sea level curves. As mentioned above, we plan to address these issues in upcoming work with transient simulations and model-data comparisons through the last deglaciation. One focus will be the best-fit values of basal sliding coefficients on the continental shelves (cf. Whitehouse et al., 2012).

\section{Conclusions}

This paper has described the formulation of a 3-D ice sheet-shelf model, and presented basic validation vs. modern Antarctica. Ice dynamics in the model uses a hybrid combination of the scaled SSA and SIA equations. A parameterization of ice flux across grounding lines (Schoof, 2007) allows grounding-line migration to be captured well, even with coarse (10 to $40 \mathrm{~km})$ grid resolutions. Dynamical tests vs. higher-order models will continue to be important to verify grounding-line behavior, as the model is applied to different domains and scenarios. The model can feasibly be run on continental scales and million-year time scales. Its modern Antarctic ice distributions are reasonably realistic, due in part to an inverse-derived distribution of basal sliding coefficients (PD12).

Although the current parameterizations of sub-ice-shelf melting and calving around Antarctica yield reasonable modern and paleoclimatic results, some aspects are ad hoc and not well constrained by underlying physics. Planned future work includes improvements in sub-ice-shelf oceanic melt, coupling with regional ocean models, and exploration of iceshelf calving parameterizations that depend on surface melt and iceberg clogging that may be needed for past regrowth after marine collapses of the West Antarctic Ice Sheet.

Acknowledgements. We thank Ralf Greve and Frank Pattyn for careful and constructive reviews that have significantly helped the manuscript. This research was funded by the US National Science Foundation under awards ANT 0424589, 1043018, 25-0550-0001, and OCE-1202632.

Edited by: P. Huybrechts

\section{References}

Ackert, Jr. R. P., Mukhopadhyay, S., Pollard, D., DeConto, R. M., Putnam, A. E., and Borns, Jr. H. W.: West Antarctic Ice Sheet elevations in the Ohio Range: Geologic constraints and ice sheet modeling prior to the last highstand, Earth Plan. Sci. Lett., 307, 83-93, 2011.

Albrecht, T. and Levermann, A.: Fracture field for large-scale ice dynamics, J. Glaciol., 58, 165-176, doi:10.3189/2012JOG11J191, 2012.

Albrecht, T., Martin, M., Haseloff, M., Winkelmann, R., and Levermann, A.: Parameterization for subgrid-scale motion of ice-shelf calving fronts, The Cryosphere, 5, 35-44, doi:10.5194/tc-5-352011, 2011.

Alley, R. B. and Whillans, I. M.: Response of the East Antarctic Ice Sheet to sea-level rise, J. Geophys. Res., 89, 6487-6493, 1984.

Alley, R. B., Anandakrishnan, S., Dupont, T. K., Parizek, B. R., and Pollard, D.: Effect of sedimentation on ice-sheet grounding-line stability, Science, 315, 1838-1841, 2007.

Alley, R. B., Horgan, H. J., Joughin, I., Cuffey, K. M., Dupont, T. K., Parizek, B. R., Anandakrishnan, S., and Bassis, J.: A simple law for ice-shelf calving, Science, 322, 1344, 2008.

Amundson, J. and Truffer, M.: A unifying framework for icebergcalving models, J. Glaciol., 56, 822-830, 2010.

Andrews, J. T. and Mahaffy M. A. W.: Growth rate of the Laurentide Ice Sheet and sea level lowering (with emphasis on the 115000 BP sea level low), Quat. Res., 6, 167-183, 1976.

Beckmann, A. and Goose, H.: A parameterization of ice shelf-ocean interaction for climate models, Ocean Modell., 5, 157-170, 2003.

Benn, D. I., Warren C. R., and Mottram, R. H.: Calving processes and the dynamics of calving glaciers, Earth-Sci. Rev., 82, 143179, 2007.

Bindschadler, R. A., Nowicki, S., Abe-Ouchi, A., Aschwanden, A., Choi, H., Fastook, J., Granzow, G., Greve, R., Gutowski, G., Herzfeld, U., Jackson, C., Johnson, J., Khroulev, C., Levermann, 
A., Lipscomb, W. H., Martin, M. A., Morlighem, M., Parizek, B. R., Pollard, D., Price, S. F., Ren, D., Saito, F., Sato, T., Seddik, H., Seroussi, H., Takahashi, K., Walker, R., and Wang, W. L.: Icesheet model sensitivities to environmental forcing and their use in projecting future sea-level (the SeaRISE project), J. Glaciol., submitted, 2012.

Briggs, R., Pollard, D., and Tarasov, L.: Past evolution of the Antarctic Ice Sheet: a Bayesian calibrated 3D glacial system modeling study. Abstract PS19.9, Programme and Abstracts, 11th International Symposium on Antarctic Earth Sciences, Edinburgh, Scotland, 246 pp., 10-16 July 2011.

Brotchie, J. F. and Silvester, R.: On crustal flexure, J. Geophys. Res., 74, 22, 5240-5252, 1969.

Budd, W. F. and Smith, I. N.: The growth and retreat of ice sheets in response to orbital radiation changes, in: Sea Level, Ice and Climatic Change, Int. Assoc. Hydrol. Sci. publ., 131, 369-409, 1979.

Budd, W. F., Jenssen, D., Mavrakis, E., and Coutts, B.: Modelling the Antarctic ice-sheet changes through time, Ann. Glaciol., 20, 291-297, 1994.

Bueler, E. and Brown, J.: Shallow shelf approximation as a "sliding law" in a thermomechanically coupled ice sheet model, J. Geophys. Res., 114, F03008, doi:10.1029/2008JF001179, 2009.

Calov, R., Greve, R., Abe-Ouchi, A., Bueler, E. L., Huybrechts, P., Johnson, J. V., Pattyn, F., Pollard, D., Ritz, C., Saito, F., and Tarasov, L.: Results from the Ice Sheet Model Intercomparison Project - Heinrich Event INtercOmparison (ISMIP HEINO), J. Glaciol., 56, 371-383, 2010.

Comiso, J. C.: Variability and trends in Antarctic surface temperatures from in situ and satellite infrared measurements, J. Climate, 13, 1674-1696, 2000.

Cuffey, K. M. and Paterson, W. S. B.: The Physics of Glaciers, Fourth Edition. Academic Press, Amsterdam, 704 pp., 2010.

DeConto, R. M. and Pollard, D.: Rapid Cenozoic glaciation of Antarctica induced by declining atmospheric $\mathrm{CO}_{2}$, Nature, 421, 245-249, 2003a.

DeConto, R. M. and Pollard, D.: A coupled climate-ice sheet modeling approach to the early Cenozoic history of the Antarctic ice sheet, Palaeogeogr. Palaeocl., 198, 39-52, 2003 b.

DeConto, R., Pollard, D., and Harwood, D.: Sea ice feedback and Cenozoic evolution of Antarctic climate and ice sheets, Paleoceanography, 22, PA3214, doi:10.1029/2006PA001350, 2007.

DeConto, R. M., Pollard, D., Wilson, P., Palike, H., Lear, C., and Pagani, M.: Thresholds for Cenozoic bipolar glaciation, Nature, 455, 653-656, 2008.

DeConto, R. M., Pollard, D., and Kowalewski, D.: Past and future vulnerability of the West Antarctic Ice Sheet to surface iceshelf melt. Abstract C42A-06, American Geophysical Union Fall Meeting, San Francisco, California, USA, December 4-9 2011.

DeConto, R. M., Pollard, D., and Kowalewski, D.: Modeling Antarctic ice sheet and climate variations during Marine Isotope Stage 31, Glob. Plan. Change, 88-89, 45-52, 2012.

Dinniman, M. S., Klinck, J. M., and Smith, Jr. W. O.: A model study of Circumpolar Deep Water on the Wext Antarctic Peninsula and Ross Sea continental shelves, Deep-Sea Res. Pt. II, 58, 15081523, 2011.

Doake, C. S. M., Corr, H. F. J., Rott, H., Skvarca, P., and Young, N. W.: Breakup and conditions for stability of the northern Larsen Ice Shelf, Antarctica, Nature, 391, 778-780, 1998.
Docquier, D., Perichon, L., and Pattyn, F.: Representing grounding line dynamics in numerical ice sheet models: Recent advances and outlook, Surveys Geophys., 32, 417-435, 2011.

Drouet, A.-S., Durand, G., Favier, L., Peyaud, V., Gagliardini, O., Ritz, C., Zwinger, T., and Le Meur, E.: Testing the validity of the boundary layer flux-thickness relationship at the grounding line, Geophys. Res. Abstr., 13, EGU2011-3149-1, European Geosciences Union General Assembly, Vienna, Austria, 2011.

Farrow, D. E. and Stevens, D. P.: A new tracer advection scheme for Bryan and Cox type ocean general circulation models, J. Phys. Oceanogr., 25, 1731-1741, 1995.

Favier, L., Gagliardini, O., Durand, G., and Zwinger, T.: A threedimensional full Stokes model of the grounding line dynamics: effect of a pinning point beneath the ice shelf, The Cryosphere, 6, 101-112, doi:10.5194/tc-6-101-2012, 2012.

Fox Maule, C., Purucker, M. E., Olsen, N., and Mosegaard, K.: Heat flux anomalies in Antarctica revealed by satellite magnetic data, Science, 309, 464-467, 2005.

Fricker, H. A., Coleman, R., Padman, L., Scambos, T. A., Bohlander, J., and Brunt, K. M.: Mapping the grounding zone of the Amery ice Shelf, East Antarctica, using InSAR, MODIS and ICESat, Antarc. Sci., 21, 515-532, 2009.

Fyke, J. G., Weaver, A. J., Pollard, D., Eby, M., Carter, L., and Mackintosh, A.: A new coupled ice sheet/climate model: description and sensitivity to model physics under Eemian, Last Glacial Maximum, late Holocene and modern climate conditions, Geosci. Model Dev., 4, 117-136, doi:10.5194/gmd-4-1172011, 2011.

Gagliardini, O., Durand, G., Zwinger, T., Hindmarsh, R. C. A., and Le Meur, E.: Coupling of ice-shelf melting and buttressing is a key process in ice-sheets dynamics, Geophys. Res. Lett., 37, L14501, doi:10.1029/2010GL043334, 2010.

Gladstone, R. M., Lee, V., Vieli, A., and Payne, A. J.: Grounding line migration in an adaptive mesh ice sheet model, J. Geophys. Res., 115, F04014, doi:10.1029/2009JF001615, 2010a.

Gladstone, R. M., Payne, A. J., and Cornford, S. L.: Parameterising the grounding line in flow-line ice sheet models, The Cryosphere, 4, 605-619, doi:10.5194/tc-4-605-2010, 2010b.

Gladstone, R. M., Payne, A. J., and Cornford, S. L.: Resolution requirements for grounding-line modelling: sensitivity to basal drag and ice-shelf buttressing, Ann. Glaciol., 53, 97-105, 2012a.

Gladstone, R. M., Lee, V., Rougier, J., Payne, A. J., Hellmer, H., Le Brocq, A., Shepherd, A., Edwards, T. L., Gregory, J., and Cornford, S. L.: Calibrated prediction of Pine Island Glacier retreat during the $21 \mathrm{st}$ and 22nd centuries with a coupled flowline model, Earth Plan. Sci. Lett., 333-334, 191-199, 2012b.

Goldberg, D. N.: A variationally derived, depth-integrated approximation to a higher-order glaciological flow model, J. Glac, 57, 201, 157-170, 2011.

Goldberg, D. N., Holland, D. M., and Schoof, C.: Grounding line movement and ice shelf buttressing in marine ice sheets, J. Geophys. Res., 114, F04026, doi:10.1029/2008JF001227, 2009.

Gomez, N., Pollard, D., Mitrovica, J. X., Huybers, P., and Clark, P. U.: Evolution of a coupled marine ice sheetsea level model, J. Geophys. Res.-Earth Surf., 117, F01013, doi:10.1029/2011JF002128, 2012.

Gudmundsson, G. H., Krug, J., Durand, G., Favier, L., and Gagliardini, O.: The stability of grounding lines on retrograde slopes, The Cryosphere Discuss., 6, 2597-2619, doi:10.5194/tcd-6- 
2597-2012, 2012.

Hellmer, H. H., Kauker, F., Timmermann, R., Determann, J., and Rae, J.: Twenty-first-century warming of a large Antarctic iceshelf cavity by a redirected coastal current, Nature, 485, 225$228,2012$.

Herrmann, A. D., Patzkowsky, M. E., and Pollard, D.: Obliquity forcing with $8-12 x$ pre-industrial levels of atmospheric $\mathrm{pCO}_{2}$ during the late Ordovician glaciation, Geology, 31, 6, 485-488, 2003.

Herrmann, A. D., Patzkowsky, M. E., and Pollard, D.: The impact of paleogeography, $\mathrm{pCO}_{2}$, poleward ocean heat transport and sea level change on global cooling during the late Ordovician, Palaeogeogr. Palaeocl., 206, 59-74, 2004.

Hindmarsh, R. C. A.: A numerical comparison of approximations to the Stokes equations used in ice sheet and glacier flow, J. Geophys Res., 109, F01012, doi:19.1029/2003JF000065, 2004.

Holland, P. R., Jenkins, A., and Holland, D. M.: The response of ice shelf basal melting to variations in ocean temperature, J. Climate, 21, 2558-2572, 2008.

Horgan, H. J. and Anandakrishnan, S.: Static grounding lines and dynamic ice streams: Evidence from the Siple Coast, West Antarctica, Geophpys. Res. Lett., 33, L18502, doi:10.1029/2006GL027091, 2006.

Horton, D. E., Poulsen, C. J., and Pollard, D.: Orbital and $\mathrm{CO}_{2}$ forcing of late Paleozoic continental ice sheets, Geophys. Res. Lett., 34, L19708, doi:10.1029/2007GL031188, 2007.

Horton, D. E., Poulsen, C. J., and Pollard, D.: Influence of highlatitude vegetation feedbacks on late Paleozoic glacial cycles, Nature Geosci., 3, 572-577, 2010.

Hubbard, A.: High-resolution modeling of the advance of the Younger Dryas ice sheet and its climate in Scotland, Quatern. Res., 52, 27-43, 1999.

Hubbard, A.: The validation and sensitivity of a model of the Icelandic ice sheet, Quatern. Sci. Rev., 25, 2297-2313, 2006.

Hulbe, C. and MacAyeal, D. R.: A new numerical model of coupled inland ice sheet, ice stream, and ice shelf flow and its application to the West Antarctic Ice Sheet, J. Geophys. Res., 104, B11, 25349-25366, 1999.

Hulbe, C. and Fahnestock, M.: Century-scale discharge stagnation and reactivation of the Ross ice streams, West Antarctica, J. Geophys. Res., 112, F03S27, doi:10.1029/2006JF000603, 2007.

Hulbe, C. L., LeDoux, C., and Cruikshank, K.: Propagation of long fractures in the Ronne Ice Shelf, Antarctica, investigated using a numerical model of fracture propagation, J. Glaciol., 56, 459472, 2010

Huybrechts, P.: Report of the Third EISMINT Workshop on Model Intercomparison, European Science Foundation, Strasbourg, 140 pp., 1998.

Huybrechts, P.: Sea-level changes at the LGM from ice-dynamic reconstructions of the Greenland and Antarctic ice sheets during the glacial cycles, Quat. Sci. Rev., 21, 203-231, 2002.

Huybrechts, P. and de Wolde, J.: The dynamic response of the Greenland and Antarctic ice sheets to multiple-century climatic warming, J. Climate, 1, 2169-2188, 1999.

Huybrechts, P. and Oerlemans, J.: Evolution of the East Antarctic Ice Sheet: a numerical study of thermomechanical response patterns with changing climate, Ann. Glaciol., 11, 52-59, 1988.

Jacobs, S. S., Jenkins, A., Giulivi, C. F., and Dutrieux, P.: Stronger ocean circulation and increased melting under Pine Island
Glacier ice shelf, Nat. Geosci., 4, 519-523, 2011.

Jenkins, A. and Bombosch, A.: Modeling the effects of frazil ice crystals on the dynamics and thermodynamics of ice shelf water plumes, J. Geophys. Res., 100, C4, 6967-6981, 1995.

Jenkins, A., Dutrieux, P., Jacobs, S. S., McPhail, S. D., Perrett, J. R., Webb, A. T., and White, D.: Observations beneath Pine Island Glacier in West Antarctica and implications for its retreat, Nature Geosci., 3, 468-472, 2010.

Katz, R. F. and Worster, M. G.: Stability of ice-sheet grounding lines, Proc. Roy. Soc. A, 466, 1597-1620, doi:10.1098/rspa.2009.0434, 2010.

Koenig, S. J., DeConto, R. M., and Pollard, D.: Late Pliocene to Pleistocene sensitivity of the Greenland Ice Sheet in response to external forcing and internal feedbacks, Clim. Dynam., 37, 1247-1268, 2011.

Laskar, J., Robutel, P., Joutel, F., Gastineau, M., Correia, A. C. M., and Levrard, B.: A long-term numerical solution for the insolation quantities of the Earth, Astron. Astophys., 428, 261-285, 2004.

Le Brocq, A. M., Payne, A. J., and Vieli, A.: An improved Antarctic dataset for high resolution numerical ice sheet models (ALBMAP v1), Earth Syst. Sci. Data, 2, 247-260, doi:10.5194/essd-2-247-2010, 2010.

Le Brocq, A. M., Bentley, M. J., Hubbard, A., Fogwill, C. J., Sugden, D. E., and Whitehouse, P. L.: Reconstructing the Last Glacial Maximum ice sheet in the Weddell Sea embayment, Antarctica, using numerical modeling constrained by field evidence, Quat. Sci. Rev., 30, 2422-2432, 2011.

Levermann, A., Albrecht, T., Winkelmann, R., Martin, M. A., Haseloff, M., and Joughin, I.: Kinematic first-order calving law implies potential for abrupt ice-shelf retreat, The Cryosphere, 6 , 273-286, doi:10.5194/tc-6-273-2012, 2012.

Lisiecki, L. E. and Raymo, M.: A Pliocene-Pleistocene stack of 57 globally distributed benthic $\delta^{18} \mathrm{O}$ records, Paleoceanogr., 20, 117, 2005.

Ma, Y., Gagliardini, O., Ritz, C., Gillet-Chaulet, F., Durand, G., and Montagnat, M.: Enhancement factors for grounded ice and ice shelves inferred from an anisotropic ice-flow model, J. Glaciool., 56, 805-812, 2010.

MacAyeal, D. R.: Large-scale ice flow over a viscous basal sediment: theory and application to Ice Stream B, Antarctica, J. Geophys. Res., 94, 4071-4087, 1989.

MacAyeal, D. R.: EISMINT: Lessons in Ice-Sheet Modeling. Dept.of Geophysical Sciences, Univ. of Chicago, 428 pp., geosci.uchicago.edu/pdfs/macayeal/lessons.pdf, 1996.

Mackintosh, A., Golledge, N., Domack, E., Dunbar, R., Leventer, A., White, D., Pollard, D., DeConto, R.M., Fink, D., Zwartz, D., Gore, D., and Lavoie, C.: Retreat of the East Antarctic ice sheet during the last glacial termination, Nat. Geosci., 4, 195202, 2011.

Mahaffy, M. W.: A Three-Dimensional Numerical Model of Ice Sheets: Tests on the Barnes Ice Cap, Northwest Territories. J. Geophys. Res., 81, 1059-1066, 1976.

Marshall, S. J. and Clarke, G. K. C.: A continuum mixture model of ice stream thermodynamics in the Laurentide Ice Sheet, J. Geophys. Res., 1021, B9, 20599-20613, 1997.

Marshall, S. J., Pollard, D., Hostetler, S., and Clark, P. U.: Coupling ice-sheet and climate models for simulation of former ice sheets, in: The Quaternary Period in the United States, edited by: 
Gillespie, A. R., Porter, S. C., and Atwater, B. F., Developments Quatern. Sci., 1, Elsevier, Amsterdam, 105-126, 2004.

Marshall, S. J., Bjornsson, H., Flowers, G. E., and Clarke, G. K. C.: Simulation of Vatnajokull ice cap dynamics, J. Geophys. Res., 110, F03009, doi:10.1029/2004JF000262, 2005.

Martin, M. A., Winkelmann, R., Haseloff, M., Albrecht, T., Bueler, E., Khroulev, C., and Levermann, A.: The Potsdam Parallel Ice Sheet Model (PISM-PIK) - Part 2: Dynamic equilibrium simulation of the Antarctic ice sheet, The Cryosphere, 5, 727-740, doi:10.5194/tc-5-727-2011, 2011.

Morland, L. W.: Unconfined ice-shelf flow, in: Dynamics of the West Antarctic Ice Sheet, edited by: van der Veen, C. J. and Oerlemans, J., Springer, New York, 99-116, 1987.

Morlighem, M., Rignot, E., Seroussi, H., Larour, E., Ben Dhia, H., and Aubry, D.: Spatial patterns of basal drag inferred using control methods from a full-Stokes and simpler models for Pine Island Glacier, West Antarctica, Geophys. Res. Lett., 37, L14502, doi:10.1029/2010GL043853, 2010.

Motyka, R., Hunter, L., Echelmeyer, L., and Connor, C.: Submarine melting at the terminus of a temperate tidewater glacier, Leconte Glacier, Alaska, USA, Ann. Glaciol., 36, 57-65, 2003.

Mukhopadhyay, S., Ackert, R. P. Jr., Pope, A. E., Pollard, D., and DeConto, R. M.: Miocene to recent ice elevation variations from the interior of the West Antarctic ice sheet: Constraints from geologic observations, cosmogenic nuclides and ice sheet modeling, Earth Plan. Sci. Lett., 337-338, 243-251, 2012.

Nicholls, K. W., Osterhus, S., Makinson, K., Gammelsrod, T., and Fahrbach, E.: Ice-ocean processes over the continental shelf of the southern Weddell Sea, Antarctica: a review, Rev. Geophys. 47, 1-23, 2009.

Nick, F. M., van der Veen, C. J., Vieli, A., and Benn, D. I.: A physically based calving model applied to marine outlet glaciers and implications for the glacier dynamics, J. Glaciol., 56, 199, 781794, 2010.

Olbers, D. and Hellmer, H.: A box model of circulation and melting in ice shelf caverns, Ocean Dynam., 60, 141-153, 2010.

Pattyn, F.: Transient glacier response with a higher-order numerical ice-flow model, J. Glaciol., 48, 467-477, 2002.

Pattyn, F., Perichon, L., Aschwanden, A., Breuer, B., de Smedt, B., Gagliardini, O., Gudmundsson, G. H., Hindmarsh, R. C. A., Hubbard, A., Johnson, J. V., Kleiner, T., Konovalov, Y., Martin, C., Payne, A. J., Pollard, D., Price, S., Rückamp, M., Saito, F., Soucek, O., Sugiyama, S., and Zwinger, T.: Benchmark experiments for higher-order and full-Stokes ice sheet models (ISMIPHOM), The Cryosphere, 2, 95-108, doi:10.5194/tc-2-95-2008, 2008.

Pattyn, F.: Antarctic subglacial conditions inferred from a hybrid ice sheet/stream model, Earth Plan. Sci. Lett., 295, 451-461, 2010.

Pattyn, F., Schoof, C., Perichon, L., Hindmarsh, R. C. A., Bueler, E., de Fleurian, B., Durand, G., Gagliardini, O., Gladstone, R., Goldberg, D., Gudmundsson, G. H., Huybrechts, P., Lee, V., Nick, F. M., Payne, A. J., Pollard, D., Rybak, O., Saito, F., and Vieli, A.: Results of the Marine Ice Sheet Model Intercomparison Project, MISMIP, The Cryosphere, 6, 573-588, doi:10.5194/tc6-573-2012, 2012a.

Pattyn, F., Perichon, L., Durand, G., Favier, L., Gagliardini, O., Hindmarsh, R. C. A., Zwinger, T., Albrecht, T., Cornford, S., Docquier, D., Furst, J. J., Goldberg, D., Gudmundsson, G. H., Humbert, A., Hutten, M., Huybrechts, P., Jouvet, G., Kleiner,
T., Larour, E., Martin, D., Morlighem, M., Payne, A. J., Pollard, D., Ruckamp, M., Rybak, O., Seroussi, H., Thoma, M., and Wilkens, N.: Grounding-line migration in plan-view marine icesheet models: results of the ice2sea MISMIP3d intercomparison, J. Glaciol., submitted, 2012b.

Payne, A. J.: A thermomechanical model of ice flow in West Antarctica, Clim. Dynam., 15, 115-125, 1999.

Payne, A. J., Holland, P. R., Shepherd, A. P., Rutt, I. C., Jenkins, A., and Joughin, I.: Numerical modeling of ocean-ice interactions under Pine Island Bay's ice shelf, J. Geophys. Res., 112, C10019, doi:10.1029/2006JC003733, 2007.

Pollard, D. and DeConto, R. M.: Antarctic ice and sediment flux in the Oligocene simulated by a climate-ice sheet-sediment model, Palaeogeogr. Palaeocl., 198, 53-67, 2003.

Pollard, D. and DeConto, R. M.: Hysteresis in Cenozoic Antarctic ice sheet variations, Glob. Planet. Change, 45, 9-21, doi:10.1016/j.gloplacha.2004.09.011, 2005.

Pollard, D. and DeConto, R. M.: A coupled ice-sheet/iceshelf/sediment model applied to a marine-margin flowline: forced and unforced variations, in: Glacial Sedimentary Processes and Products, edited by: Hambrey, M. J., Christoffersen, P., Glasser, N. F., and Hubbard, B., International Association of Sedimentologists Special Publication, 39, Blackwell Publ., Oxford, 37-52, 2007.

Pollard, D. and DeConto, R. M.: Modelling West Antarctic ice sheet growth and collapse through the past five million years, Nature, 458, 329-332, 2009.

Pollard, D. and DeConto, R. M.: Antarctic Ice Sheet variations in response to changes in ice-shelf oceanic melting. Abstract, International Glaciological Society (IGS) Symposium on Interactions of Ice Sheets and Glaciers with the Ocean, 5-10 June 2011, Scripps Institution of Oceanography, California, USA, 2011.

Pollard, D. and DeConto, R. M.: A simple inverse method for the distribution of basal sliding coefficients under ice sheets, applied to Antarctica, The Cryosphere, 6, 953-971, doi:10.5194/tc-6953-2012, 2012.

Pollard, D. and Kasting, J. F.: Climate-ice sheet simulations of Neoproterozoic glaciation before and after collapse to Snowball Earth, in: The Extreme Proterozoic: Geology, Geochemistry and Climate, edited by: Jenkins, G., McMenamin, M., McKay, C., and Sohl, L.: Geophysical Monograph 146, American Geophysical Union, Washington, D. C., 91-105, 2004.

Pollard, D., DeConto, R. M., and Nyblade, A. A.: Sensitivity of Cenozoic Antarctic ice sheet variations to geothermal heat flux, Glob. Planet. Change, 49, 63-74, 2005.

Pritchard, H. D., Ligtenberg, S. R. M., Fricker, H. A., Vaughan, D. G., van den Broeke, M. R., and Padman, L.: Antarctic ice-sheet loss driven by basal melting of shelves, Nature, 484, 502-505, 2012.

Rignot, E., Koppes, M., and Velicogna, I.: Rapid submarine melting of the calving faces of West Greenland glaciers, Nature Geosci., 3, 187-191, 2010.

Rignot, E., Mouginot, J., and Scheuchl, B.: Ice flow of the Antarctic Ice Sheet, Science, 333, 1428-1430, 2011.

Ritz, C., Fabre, A., and Letreguilly, A.: Sensitivity of a Greenland ice sheet model to ice flow and ablation parameters: consequences for the evolution through the last climatic cycle, Clim. Dynam., 13, 11-24, 1997. 
Ritz, C., Rommelaere, V., and Dumas, C.: Modeling the evolution of Antarctic ice sheet over the last 420000 years: Implications for altitude changes in the Vostok region, J. Geophys. Res., 106, D23, 31943-31964, 2001.

Rogozhina, I., Hagedoorn, J. M., Martinec, Z., Fleming, K., Soucek, O., Greve, R., and Thomas, M.: Effects of uncertainties in the geothermal heat flux distribution on the Greenland Ice Sheet: An assessment of existing heat flow models, J. Geophys. Res., 117, F02025, doi:10.1029/2011JF002098, 2012.

Rommelaere, V. and Ritz, C.: A thermomechanical model of iceshelf flow, Ann. Glaciol., 23, 13-20, 1996.

Scambos, T. A., Bohlander, J. A., Shuman, C. A., and Skvarca, P.: Glacier acceleration and thinning after ice shelf collapse in the Larsen B embayment, Antarctica, Geophys. Res. Lett., 31, L18402, doi:10.1029/2004GL020670, 2004.

Schoof, C.: Ice sheet grounding line dynamics: Steady states, stability, and hysteresis, J. Geophys. Res., 112, F03S28, doi:10.1029/2006JF000664, 2007.

Schoof, C. and Hindmarsh, R. C. A.: Thin-film flows with wall slip: An asymptotic analysis of higher order glacier flow models, Q. J. Mech. Appl. Math., 63, 73-114, 2010.

Seddik, H., Greve, R., Zwinger, T., Gillet-Chaulet, F., and Gagliardini, O.: Simulations of the Greenland ice sheet 100 years into the future with the full Stokes model Elmer/Ice, J. Glaciol., 58, 209, 427-440, 2012.

Shapiro, N. M. and Ritzwoller, M. H.: Inferring surface heat flux distributions guided by a global seismic model: particular application to Antarctica. Earth Plan. Sci. Lett., 223, 213-224, 2004.

Smith, N. R., Zhaoqian, D., Kerry, K. R., and Wright, S.: Water masses and circulation in the region of Prydz Bay, Antarctica, Deep-Sea Res., 31, 1121-1147, 1984.

Stern, T. A. and ten Brink, U. S.: Flexural uplift of the Transantarctic Mountains, J. Geophys. Res., 94, B8, 10315-10330, 1989.

Studinger, M., Bell, R. E., Blankenship, D. D., Finn, C. A., Arko, R. A., Morse, D. L., and Joughin, I.: Subglacial sediments: A regional geological template for ice flow in West Antarctica, Geophys. Res. Lett., 28, 18, 3493-3496, 2001.

Timmermann, R., Le Brocq, A., Deen, T., Domack, E., Dutrieux, P., Galton-Fenzi, B., Hellmer, H., Humbert, A., Jansen, D., Jenkins, A., Lambrecht, A., Makinson, K., Niederjasper, F., Nitsche, F., Nost, O. A., Smedsrud, L. H., and Smith, W. H. F.: A consistent data set of Antarctic ice sheet topography, cavity geometry, and global bathymetry, Earth. Syst. Sci. Data, 2, 261-273, doi:10.5194/essd-2-261-2010, 2010.
Tziperman, E., Abbot, D. S., Ashkenazy, Y., Gildor, H., Pollard, D., Schoof, C. G., and Schrag, D. P.: Continental constriction and sea ice thickness in a Snowball-Earth scenario, J. Geophys. Res.Oceans, 117, C05016, 12 pp., doi:10.1029/2011JC007730, 2012.

van de Berg, W. J., van den Broeke M. R., and van Meijgaard, E.: Reassessment of the Antarctic surface mass balance using calibrated output of a regional atmospheric climate model, J. Geophys. Res., 111, D11104, doi:10.1029/2005JD006495, 2006.

van de Berg, W. J., van den Broeke, M., Ettema, J., van Meijgaard, E., and Kaspar, F.: Significant contribution of insolation to Eemian melting of the Greenland ice sheet, Nature Geosci., 4, 679-683, 2011.

van den Berg, J., van de Wal, R. S. W., and Oerlemans, J.: Effects of spatial discretization in ice-sheet modelling using the shallow-ice approximation, J. Glaciol., 52, 176, 89-98, 2006.

van der Veen, C. J.: Response of a marine ice sheet to changes at the grounding line, Quatern. Res., 24, 257-267, 1985.

Vaughan, D. G., Barnes, D. K. A., Fretwell, P. T., and Bingham, R. G.: Potential seaways across West Antarctica, Geochem. Geophys. Geosyst., 12, Q10004, doi:10.1029/2011GC003688, 2011.

Walker, R. T., Dupont, T. K., Holland, D. M., Parizek, B. R., and Alley, R. B.: Initial effects of oceanic warming on a coupled oceanice shelf-ice stream system, Earth Plan. Sci. Lett., 287, 483-487, 2009.

Whitehouse, P. L., Bentley, M. J., and Le Brocq, A. M.: A deglacial model for Antarctica: geological constraints and glaciological modeling as a basis for a new model of Antarctic glacial isostatic adjustment, Quat. Sci. Rev., 32, 1-24, 2012.

Winkelmann, R., Martin, M. A., Haseloff, M., Albrecht, T., Bueler, E., Khroulev, C., and Levermann, A.: The Potsdam Parallel Ice Sheet Model (PISM-PIK) - Part 1: Model description, The Cryosphere, 5, 715-726, doi:10.5194/tc-5-715-2011, 2011.

Winkelmann, R., Levermann, A., Frieler, K., and Martin, M. A.: Uncertainty in future solid ice discharge from Antarctica, The Cryosphere Discuss., 6, 673-714, doi:10.5194/tcd-6-673-2012, 2012.

Young, D. A., Wright, A. P., Roberts, J. L., Warner, R. C., Young, N. W., Greenbaum, J. S., Schroeder, D. M., Holt, J. W., Sugden, D. E., Blankenship, D. D., van Ommen, T. D., and Siegert, M. J.: A dynamic early East Antarctic Ice Sheet suggested by ice-covered fjord landscapes, Nature, 474, 72-75, 2011. 